\title{
A Model Compound Study: The Ecotoxicological evaluation of five organic contaminants employing a battery of marine bioassays
}

$\underline{\text { Ailbhe Macken }^{\text {a, }}}{ }^{*}$, Michelle Giltrap ${ }^{\text {a, c }}$, Barry Foley ${ }^{\text {b }}$, Evin McGovern ${ }^{\text {c }}$, Brendan McHugh ${ }^{\mathrm{c}}$, Maria Davoren ${ }^{\mathrm{a}}$

${ }^{a}$ Radiation and Environmental Science Centre, Focas Institute, DIT, Kevin St., Dublin 8, Ireland.

${ }^{\mathbf{b}}$ School of Chemical and Pharmaceutical Sciences, DIT, Kevin St., Dublin 8, Ireland.

${ }^{\mathbf{c}}$ The Marine Institute, Rinville, Oranmore, Co. Galway, Ireland.

Email Addresses: Ailbhe Macken ailbhe.macken@dit.ie

Michelle Giltrap michelle.giltrap@ marine.ie

Barry Foley barry.foley@dit.ie

Evin McGovern evin.mcgovern@marine.ie

Brendan McHugh brendan.mchugh@marine.ie

Maria Davoren maria.davoren@ dit.ie 


\section{ABSTRACT}

This paper describes the ecotoxicological evaluation of five organic contaminants frequently detected in marine sediments (tributyltin, triphenyltin, benzo[a]pyrene, fluoranthene, and PCB 153) using three marine species (Vibrio fischeri,, Tetraselmis suecica, and Tisbe battagliai). The sensitivity of each species varied for all compounds. The tri-organotins were consistently the most toxic to all species.. The applicability of each test system to asses the acute toxicity of environmental contaminants and their use in Toxicity Identification Evaluation (TIE) is discussed. Suitability of the Microtox and T. battagliai tests for employment in TIE studies were further assessed through spiking experiments with. tributyltin Results demonstrated that the most effective treatment to remove organotin toxicity from the sample was the $\mathrm{C}_{18}$ resin. The results of this study have important implications for risk assessment in estuarine and coastal waters in Ireland, where, at present the monitoring of sediment and water quality is predominantly reliant on chemical analysis alone.

* Corresponding author. Tel.: +353 1 4027975; fax: +353 14027904 E-mail Address: ailbhe.macken@dit.ie (A. Macken) 


\section{Introduction}

In recent years there has been growing concern regarding the toxic effects of chemical substances entering the aquatic environment. Sediments have been recognized as a major repository for persistent toxic substances released in the aquatic environment and frequently contain higher concentrations of pollutants than are found in the water column (Tolun et al., 2001). Persistent contaminants can ultimately enter into coastal areas and estuaries and may have short term (heavy metals, chlorophenol) or long term negative biological effects (polychlorinated biphenyls [PCBs] and polycyclic aromatic hydrocarbons [PAHs]), (Burton, 1991). Contaminants accumulate in the sediment and have the potential to cause adverse effects to indigenous biota and aquatic organisms should they become remobilised or bioavailable following chemical (e.g. changes in $\mathrm{pH}$, salinity fluctuations), physical (e.g. dredging) or biological (bioturbation) processes. The monitoring of contaminants is therefore a vital part of any water quality monitoring programme.

In comparison to the extensive range of information available on the toxicity of chemical substances to freshwater organisms, there is relatively limited data on the effects of these substances on marine and estuarine species and especially on species occurring in Irish waters. Ecotoxicological activity of single chemicals can reasonably be assessed by current standardised bioassays. Although bioassays are not precise indicators of environmental effects, they are regarded as the best available method for integrating the effects of multiple contaminants.

Assessment and monitoring of the effects of pollutants in Irish marine sediments on marine organisms requires knowledge of the main toxic substances involved. Determination of acute aquatic toxicity of a chemical species is critical for 
the evaluation of potential adverse environmental impacts from industrial and other point sources (Utgikar et al., 2004). Ecotoxicological data obtained may also allow for the prediction of "safe" levels in the environment. Five relevant chemical pollutants representing a diverse range of contaminants were selected for this study namely, two organotin compounds, two PAHs and a PCB compound. A summary of ecotoxicity data identified in the literature for the selected battery of bioassays and these chemicals is presented in Table 1.

Past and present usage of organotin compounds especially tributyl (TBT) and triphenyl (TPT) tins are recognised as being of great environmental concern. Tributyltin has been used in Ireland in antifouling paints on submerged marine structures such as boat hulls and salmon cages since the 1960s. An Irish bye-law was passed in April 1987 (Anon., 1987), prohibiting the use of TBT based paints on all vessels under $25 \mathrm{~m}$ except under special circumstances and other submerged marine structures such as salmon cages. Several marine ecotoxicological studies were initiated throughout Europe in the early 1980s after harmful effects were observed in commercial oyster-growing areas in France and Great Britain (Alzieu, 1996). Unlike inorganic tins, which do not accumulate in living organisms, tributyltin is bioconcentrated by bacteria, phytoplankton, molluscs, crustaceans and fish. Toxicity varies considerably between species and taxonomic groups (Alzieu, 1996); however, TBT is highly toxic to algae, molluscs, crustacean and fish. It has also been identified as an endocrine disrupting substance. Some neogastropods are extremely sensitive to TBT and it has been observed to causes imposex in pelagic female larval stages of gastropods at concentrations as low as $1 \mathrm{ng} / \mathrm{L}$ (Bryan et al., 1986). Tributyltin has also been observed to cause shell thickening in the Pacific Oyster (Minchin et al., 1996). Tributyltin degrades quickly in seawater where it has a residence time of days, 
but it tends to adsorb onto particles and aggregates in sediments where the degradation processes are considerably slower. Despite the banning of organotinbased paints containing TBT and TPT in many European countries, and the existence of the Water Framework Directive requiring organotin levels in the marine environment to be monitored regularly from this year forward, the presence of both compounds is still of concern in the marine environment. In 2001, the U.S. EPA reviewed the use of TPT as a fungicide and determined that its benefits continued to outweigh its risks. Ten Hallers-Tjabbes et al., (2003) found that TPT had a low potential to induce imposex compared to TBT but Horiguchi et al., (1997) found the potential of the two compounds was similar.

Polycyclic aromatic hydrocarbons encompass a wide range of naturally occurring and non-naturally occurring chemicals. They may be derived from three sources: fossil fuels (petrogenic), burning of organic matter (pyrogenic) and by the transformation of natural organic matter in the environment through diagenetic processes. Due to their hydrophobicity, PAHs in the aquatic environment become associated with suspended particulate matter and are subsequently deposited in the sediments (Chiou et al., 1998). Due to their carcinogenic properties and anthropogenic origin there has been great interest in their fate and toxicity in the environment in recent years. One of the most abundant PAH pollutants in the environment is fluoranthene, a four ringed PAH. The majority of toxicity data available is concerned with acute exposure with limited information on chronic exposures. El-Alawi et al., (2002) and Barata et al., (2002) reported $\mathrm{EC}_{50}$ and $\mathrm{LC}_{50}$ for Vibrio fischeri and Tisbe battagliai respectively after exposure to fluoranthene (Table 1), but data on other marine organisms remains limited. Benzo[a]pyrene, a readily detectable PAH contaminant of marine sediments is highly persistent and is a 
known carcinogen. Like fluoranthene, limited toxicity data exists in the literature for marine species.

Polychlorinated biphenyls are a group of synthetic organic chemicals that have been banned in most industrialised countries since the 1980s. While no natural sources of PCBs exist they can enter the aquatic environment through leakage, recycling, transboundary influx via major rivers and long-range atmospheric transport (Ockenden et al., 1998). PCBs are persistent in the environment and are biomagnified up the food chain and have been found in top predators in the marine environment (Leonards et al., 1997). The congener PCB 153 was selected for this study, primarily on the basis of its relative environmental persistence and as it is routinely monitored in Ireland in sediments and biota. To the best of our knowledge no toxicity data exists in the literature for PCB 153 for the test species used in this study.

Sediment porewater is defined as the water occupying the space between sediment particles (Ingersoll, 2003). It is of interest in sediment assessment as it contains the water-soluble, bioavailable fraction of contaminants and as a result, is considered to be a major route of contaminant exposure to indigenous biota. Sediment Toxicity Identification Evaluation (TIE) techniques are used in sediment assessment to identify biologically active compounds employing a bioassay directed fractionation procedure. Currently, there is no single standardized approach for conducting marine sediment TIE procedures however, there are several frequently used techniques employing marine porewaters to identify the causative agents at sites where significant toxicity is observed.

The objectives of this study were to: (1) investigate the toxicity of five OSPAR chemicals for priority action (OSPAR, 2005) with a battery of three marine bioassays comprising of bacteria (Vibrio fischeri), a microalgae (Tetraselmis suecica), 
and a harpacticoid copepod (Tisbe battagliai), (2) to rank the species according to sensitivity to each chemical, and (3) to identify a suitable test species and method for use in Toxicity Identification Evaluation (TIE) with sediment porewaters of suspected toxicity. 


\section{Materials and methods}

\subsection{Test substances}

The organotin compounds tributyltin chloride $\left(\mathrm{C}_{12} \mathrm{H}_{27} \mathrm{ClSn}\right.$; CAS Registry No. 1461-22-9), triphenyltin chloride $\left(\left(\mathrm{C}_{6} \mathrm{H}_{5}\right)_{3} \mathrm{SnCl}\right.$; CAS Registry No. 639-58-7) and PCB 153 (2,2', 4,4',5,5'-hexachlorobiphenyl; $\mathrm{C}_{12} \mathrm{H}_{4} \mathrm{Cl}_{6}$; CAS Registry No. 35065-271) were obtained from LGC Promochem (UK). The PAH compounds, benzo[a]pyrene [B[a]P] $\left(\mathrm{C}_{20} \mathrm{H}_{12}\right.$; CAS Registry No. 50-32-8) and fluoranthene [FLA] $\left(\mathrm{C}_{16} \mathrm{H}_{10}\right.$; CAS Registry No. 206-44-0) were obtained from Sigma Aldrich (UK). The organic solvent dimethylsulphoxide [DMSO] (Sigma, Ireland) was employed as a solubilising agent in the preparation of stock solutions of the organotins and PAH compounds. Acetone was employed as the solvent in the preparation of the PCB stock solution. Analytical grade potassium dichromate $\left(\mathrm{K}_{2} \mathrm{Cr}_{2} \mathrm{O}_{7}\right.$; CAS Registry No 778-50-9) and phenol $\left(\mathrm{C}_{6} \mathrm{H}_{6} \mathrm{O}\right.$; CAS Registry No. 108-95-2) were obtained from Sigma Aldrich (UK) and BDH (UK) respectively and were employed as reference toxicants to validate the test procedures. Chemical structures of all test compounds are shown in Figure 1. All test compounds chosen are known/detectable pollutants of the estuarine/marine environment in Ireland (Kilemade et al., 2004; Davoren et al., 2005; Cronin et al., 2006).

\subsection{Ecotoxicity tests}

For all tests, and for each test chemical, testing was performed in two stages. A preliminary range finding test was conducted to determine the range of concentrations to be tested in the definitive test. Maximum allowable concentrations (MACs) for DMSO and acetone were determined for all species before preliminary 
and subsequent definitive testing. All definitive testing was conducted in at least triplicate on three independent occasions. All tests, blanks and positive controls (reference chemicals) with the exception of the Microtox ${ }^{\circledR}$ test were conducted with natural seawater collected from the Bull Lagoon, Co. Dublin, Ireland $\left(53^{\circ} 22^{\prime} \mathrm{N}\right.$ $006^{\circ} 08^{\prime} \mathrm{W}$ ) with a salinity range of 29-32\%o. Algal species and T. battagliai were maintained in the laboratory in accordance with standard methods (BS EN ISO 10253, 1998; ISO/DIS 14669, 1997). The culture and testing of all species was carried out in the Radiation and Environmental Science Centre (RESC). The selection of test species was based on their standardisation and frequent employment in toxicity testing, reported sensitivity to a wide range of pollutants and their relevance to an Irish environment.

\subsubsection{Microtox ${ }^{\circledR}$ assay.}

Lyophilised Vibrio fischeri bacteria (NRRL B-11177) and all Microtox ${ }^{\circledR}$ reagents were obtained from SDI Europe, Hampshire, UK. The Microtox ${ }^{\circledR}$ assay was performed in accordance with operational procedures from Azur Environmental Ltd. (Azur Environmental Ltd, 1998). Five, fifteen and thirty-minute $\mathrm{EC}_{50}$ tests were performed using the $90 \%$ basic test for aqueous extracts. The $90 \%$ test was selected as it is the method routinely employed in our laboratory for the assessment of environmental samples. Bioluminescent responses were measured using a Microtox ${ }^{\circledR}$ Model 500 analyser and acute toxicity data were obtained and analyzed using the MicrotoxOmni ${ }^{\circledR}$ software (SDI Europe, Hampshire, UK). A basic test was conducted with the reference standard phenol for each fresh vial of bacteria opened to ensure validity of test method. 


\subsubsection{Microalgal toxicity test}

Tetraselmis suecica (Kylin) Butcher (CCAP66/4) was obtained from the Culture Collection of Algae and Protozoa (CCAP) (Argyll, Scotland). Toxicity tests were conducted according to the International Organization for Standardization (ISO) Guideline 10253 (BS EN ISO 10253, 1998). All microalgal growth inhibition tests were conducted at $20 \pm 1{ }^{\circ} \mathrm{C}$ with continuous shaking at $100 \mathrm{rpm}$, illumination of 10,000 lux and a continuous photoperiod. The initial algal density of all flasks was 1 $\mathrm{x} 10^{4} \mathrm{cell} / \mathrm{ml}$ in a final volume of $20 \mathrm{ml}$. Negative controls were incorporated for each test containing only algal growth media and algal inoculum. Solvent controls were run concurrently with each test. The cell density of each replicate was measured after 72 h using a Neubauer Improved (Bright-Line) chamber (Brand, Germany). Average specific growth rate $\left(\mu=\ln \left(N_{\mathrm{L}}-\ln N_{0}\right) / t_{\mathrm{L}}\right.$, where, $t_{\mathrm{L}}$ is the time in hours, between the last measurement of the exponential growth period and the beginning of the test, $N_{0}$ is the initial density and $N_{\mathrm{L}}$ is the measured cell density at time $t_{\mathrm{L}}$ ) and percentage inhibition of average specific growth rate relative to controls were calculated for each concentration. Test validity criteria required algal growth in control flasks to increase by a factor of 16 within the $72 \mathrm{~h}$ test period and $\mathrm{pH}$ not to have varied by more than \pm 1 unit during the test. The reference chemical potassium dichromate was employed as a positive control to ensure validity of test method.

\subsubsection{Copepod toxicity test}

A starting culture of Tisbe battagliai was kindly supplied by Shannon Acute Toxicity Laboratory (SATL), Ireland. T. battagliai toxicity tests were conducted with slight modifications according to the ISO method (ISO/DIS 14669, 1997). Toxicity tests with $T$. battagliai were conducted with copepodids $6 \pm 2$ days old. The 
bioassays were conducted in 12 well polystyrene plates (Corning Incorporated Costar $^{\circledR}$, New York, USA). Plates were placed in distilled water for $24 \mathrm{~h}$ before test initiation. Test plates were incubated in a temperature controlled room at $20 \pm 2{ }^{\circ} \mathrm{C}$ and under a 16:8 h light:dark photoperiod. A positive control using potassium dichromate was run alongside tests in order to verify the sensitivity of the copepods, and solvent controls were run concurrently with all tests. Lethality for each chemical at each concentration was recorded and the percentage mortality $\left(\mathrm{LC}_{50}\right)$ compared to the controls was determined after $24 \mathrm{~h}$ and $48 \mathrm{~h}$. At test termination, dissolved oxygen concentrations were greater than or equal to $4 \mathrm{mg} / \mathrm{L}$. Salinity and $\mathrm{pH}$ were controlled to within $\pm 2 \%$ or \pm 1 unit respectively. Control species mortality of less than or equal to $10 \%$ was required as a further validation parameter.

2.2.4 Toxicity Identification Evaluation: Preliminary evaluation of methods and suitability of test species

To determine the efficacy of the proposed Toxicity Identification Evaluation (TIE) methods for employment in marine porewater studies, several marine TIE manipulations were performed with spiked TBT-Cl samples and the Microtox ${ }^{\circledR}$ and Tisbe battagliai acute toxicity test systems. Starting concentrations of $0.9 \mu \mathrm{mol} / \mathrm{L}$ and $0.1 \mu \mathrm{mol} / \mathrm{L}$ for the Microtox ${ }^{\circledR}$ acute test and T. battagliai acute test respectively were employed for the manipulations. These concentrations of TBT-Cl were the same as those used for the initial toxicity testing. A Phase I Marine TIE characterization (Burgess et al., 1996) was conducted. The modified test procedure is outlined in Figure 2.

For the Microtox ${ }^{\circledR}$ manipulations spiked samples were divided into four $5 \mathrm{ml}$ portions. The first aliquot was used to measure the toxicity of the untreated samples. 
For the second and third aliquots $10 \mu \mathrm{l}$ and $17 \mu \mathrm{l}$ of ethylenediaminetetraacetic acid (EDTA) stock (74.68 mmol EDTA/L) and sodium thiosulphate stock (94.7 mmoles $\mathrm{Na}_{2} \mathrm{~S}_{2} \mathrm{O}_{3} / \mathrm{L}$ ) were added respectively. After addition of EDTA the sample was left to chelate for three hours prior to testing. In the case of the sodium thiosulphate the sample was left for one hour before testing. The fourth aliquot was passed through a methanol-activated $\mathrm{C}_{18}$ resin column (SUPELCO Discovery® DSC-18, USA). The post column sample eluate was then tested for toxicity. Due to a significant toxic effect observed with the EDTA and the $90 \%$ Microtox $^{\circledR}$ test the Basic test was employed for all spiking experiments. All tests were performed in accordance with operational procedures from Azur Environmental Ltd. (Azur Environmental Ltd, 1998) and 5, 15 and 30 min readings were recorded.

For Tisbe battagliai manipulations the spiked sample was again divided into four aliquots each of $10 \mathrm{ml}$. The first aliquot was used to measure the toxicity of the untreated sample. The second aliquot was used to prepare a six step concentration dilution series. Twenty microlitres of EDTA stock were added to each test container and after three hours $T$. battagliai were added. For the third aliquot, another identical dilution series was prepared, $34 \mu 1$ of sodium thiosulphate stock were added to each test container and after one hour the organisms were added. The final aliquot was passed through a methanol activated $\mathrm{C}_{18}$ resin and this post column sample eluant was used to prepare the six concentration dilution series. Organisms were then added immediately. All toxicity testing was conducted with slight modifications according to the ISO method (ISO/DIS 14669, 1997).

For both assays EDTA, sodium thiosulphate and post $\mathrm{C}_{18}$ column test media blanks were run concurrently. Testing was conducted on three independent occasions for both assays. 


\subsubsection{Statistical analysis}

The $\mathrm{EC}_{50}$ (concentration that elicits an estimated $50 \%$ toxic effect (e.g. growth inhibition, mortality) values for all chemicals were calculated using REGTOX-EV6.xls (Èric Vindimian http://eric.vindimian.9online.fr/), a curve fitting macro for Microsoft ${ }^{\circledR}$ Excel. For each definitive test, each concentration was tested in triplicate (microalgae) or quadruplicate (copepod tests) and three independent experiments were performed. The acute toxicity data for the Microtox ${ }^{\circledR}$ assays was analysed using the MicrotoxOmni ${ }^{\circledR}$ software (SDI Europe, Hampshire, UK). Toxicity data for the algal and copepod tests were fitted to a sigmoidal curve and the Weibull (algal assays) and Hill (copepods and bacterial assays) models were used to calculate Effective Concentration (EC) and Lethal Concentration (LC) values respectively. Statistical analyses were carried out using a one-way analyses of variance (ANOVA) followed by Dunnett's multiple comparison test. These data analyses were performed using MINITAB $^{\circledR}$ release 12 (MINITAB Inc. PA, USA). Statistical significance was accepted at $p \leq 0.05$. 


\section{Results}

Testing of reference chemicals in tandem with the organic compounds was carried out to ensure the validity of each test method. Ecotoxicity data determined from each test system and its respective reference chemical is presented in Table 2. Prior to conducting any bioassays with the organic test chemicals, the maximum allowable concentration (MAC) of the organic solvents was established. The MAC is defined as the percentage concentration of solvent that does not produce a significant effect $(p \leq 0.05)$ on the test organisms. Dimethylsulphoxide and acetone were used as carrier solvents for the organic chemicals employed in this study. The MACs for Vibrio fischeri and acetone and DMSO were both $1 \%$, those for Tetraselmis suecica were $1 \%$ (acetone) and $0.5 \%$ (DMSO) and for Tisbe battagliai the MACs were 0.1 $\%$ for both solvents. In addition, solvent controls in which acetone or DMSO was incorporated at the highest concentration present in the test solutions were run concurrently. These controls did not demonstrate any significant toxicity to the test species when compared to the media controls. The results of chemical analyses of organotin stock test solutions showed no difference between nominal and mean measurement concentrations. Stock solutions of the organotin compounds were analysed and shown to be in close agreement with nominal concentrations i.e. $\pm 8.9 \%$ for TBT (SD) and $\pm 13.2 \%$ for TPT (SD). However percentage recoveries of concentrations determined were $102.1 \%$ for TBT and $134.3 \%$ for TPT $(n=3)$ due to method variances. Concentrations for all other chemicals are reported as nominal. 


\subsection{Microtox ${ }^{\circledR}$}

The mean $\mathrm{EC}_{50}$ value for the positive phenol control (fifteen analyses) was $19.93 \mathrm{mg} / \mathrm{L}(95 \% \mathrm{CI}=15.81-25.97 \mathrm{mg} / \mathrm{L})$ which was within the recommended $\mathrm{EC}_{50}$ value range of $13.00-26.00 \mathrm{mg} / \mathrm{L}$ (Azur Environmental Ltd., 1998). Toxic responses of the five organic pollutants employing the Microtox ${ }^{\circledR}$ acute test were determined and are presented in Table 3. A time dependent decrease in light levels and resulting increase in toxicity was observed with the two organotin compounds. In contrast the $\mathrm{B}[\mathrm{a}] \mathrm{P}$ and FLA elicited their most toxic response after only $5 \mathrm{~min}$ exposure to the test organism followed by a decrease in toxicity with increasing exposure time (Table 3$)$.

A biostimulatory response was observed at low concentration $(0.004-0.014 \mu \mathrm{mol} / \mathrm{L})$ following exposure to $\mathrm{TBT}-\mathrm{Cl}$ for 5,15 and $30 \mathrm{~min}$. This stimulatory response ranged from 1 to $33 \%$ increase in light output when compared to the controls. However, this biostimulatory response was not statistically significant $(p \leq 0.05)$ when compared to the controls. Employing calculated ecotoxicity values $\left(\mathrm{EC}_{50}\right)$ a sensitivity ranking order for all chemicals to the Microtox ${ }^{\circledR}$ system is as follows: TBT $>$ TPT $>$ FLA $>$ B[a]P $>$ PCB 153.

\subsection{Microalgal toxicity test}

The mean $\mathrm{EC}_{50}$ value for the reference chemical potassium dichromate with $T$. suecica was $14.12 \mathrm{mg} / \mathrm{L}(95 \% \mathrm{CI}=11.20-15.13 \mathrm{mg} / \mathrm{L})$. No equivalent data for $T$. suecica and the reference chemical were identified in the literature. T. suecica showed great sensitivity to the organotins, $72 \mathrm{~h} \mathrm{EC} \mathrm{E}_{50}$ values were calculated to be $0.469 \mu \mathrm{mol} / \mathrm{L}$ and $0.013 \mu \mathrm{mol} / \mathrm{L}$ for $\mathrm{TBT}-\mathrm{Cl}$ and TPT-Cl respectively. Toxicity testing with the PAH Benzo[a]pyrene proved more difficult. Several range finding 
tests were conducted. Results were inconsistent and a reproducible dose-response curve was not obtained. Therefore no $\mathrm{EC}_{50}$ value was reported. Growth inhibition tests with PCB 153 also produced irregular dose-response curves with the algae and did not allow for the quantification of an accurate $\mathrm{EC}_{50}$ value. In the case of fluoranthene a maximum inhibition of $32 \%$ growth was observed at the top concentration and hence it was not possible to derive an $\mathrm{EC}_{50}$ value.

\subsection{Copepod toxicity test}

The Tisbe battagliai bioassay was performed in triplicate and yielded a $48 \mathrm{~h} \mathrm{LC}_{50}$ value of $7.42 \mathrm{mg} / \mathrm{L}(95 \% \mathrm{CI}=5.73-10.01 \mathrm{mg} / \mathrm{L})$ for the reference chemical potassium dichromate. Reference values of $1.6 \mathrm{mg} / \mathrm{L}$ ( $\mathrm{LC}_{50}$ for naupliar exposure) and $5.9 \mathrm{mg} / \mathrm{L}$ ( $\mathrm{LC}_{50}$ for adult female exposure) were reported for T. battagliai after 96 h exposure to $\mathrm{K}_{2} \mathrm{Cr}_{2} \mathrm{O}_{7}$ (Hutchinson et al., 1994) The control mortality in the acute tests with T. battagliai was less than $5 \%$ for all chemicals. All water quality parameters (salinity, temperature, $\mathrm{pH}$ and dissolved oxygen) met with International Standards Organisation guidelines (ISO/DIS, 1997). T. battagliai was significantly more sensitive to the organic solvents (DMSO and acetone) compared to the other test battery species. Toxicity data for tested compounds in the T. battalgiai test is presented in Table 4. The organotins were highly toxic to $T$. battalgiai with triphenyltin chloride $\left(48 \mathrm{~h} \mathrm{LC} 5_{50}=0.009 \mu \mathrm{mol} / \mathrm{L}\right)$ being an order of magnitude more toxic than tributyltin chloride $\left(48 \mathrm{~h} \mathrm{LC}_{50}=0.07 \mu \mathrm{mol} / \mathrm{L}\right)$. With a $48 \mathrm{~h} \mathrm{LC}_{50}$ of 4.01 $\mu \mathrm{mol} / \mathrm{L}$, the PAH, benzo[a]pyrene appeared to be the least toxic to the benthic harpacticoid. Fluoranthene was more toxic than Benzo[a]pyrene to the copepod with a $48 \mathrm{~h} \mathrm{LC}_{50}$ value of $1.19 \mu \mathrm{mol} / \mathrm{L}$. The toxicity of the organic contaminants, in decreasing order was as follows: TPT $>$ TBT $>$ PCB $153>$ FLA $>$ B $[a]$ P. 


\subsection{Toxicity Identification Evaluation: Spiking experiment results}

Figure 3 presents the results of the baseline toxicity test with TBT-Cl (initial concentration of $0.9 \mu \mathrm{mol} / \mathrm{L}$ ) and the Microtox $^{\circledR}$ system and all subsequent manipulations. From this data it can be seen that the $\mathrm{C}_{18}$ column removed all significant toxicity. Apart from the EDTA, which showed a slight increase in toxicity, there were no significant changes in toxicity after the other manipulations. The sodium thiosulphate addition had no significant effect and the $\mathrm{EC}_{50}$ values generated post manipulations were nearly identical to those of the baseline test (Table 5). Absence of toxicity in the post $\mathrm{C}_{18}$ column sample eluate suggests that organic toxicants were active in the original sample. The Microtox ${ }^{\circledR}$ Basic test employs only 4 test concentrations, whereas the $90 \%$ test for aqueous extracts uses 9 concentrations. It was not possible to identify an accurate NOEC value as this value was below the lowest concentration tested. Table 5 shows the $\mathrm{EC}_{50}$ values calculated after each manipulation. No $\mathrm{EC}_{50}$ value could be calculated for the post $\mathrm{C}_{18}$ column sample as nearly all toxicity was removed. After 15 and 30 min exposure hormesis was detected, however levels were not statistically significant.

Figure 4 shows the results of the baseline toxicity test with TBT-Cl (start concentration of $0.1 \mu \mathrm{mol} / \mathrm{L}$ ) and $T$. battagliai with all manipulations. The addition of EDTA reduced the toxicity at the top concentrations of TBT-Cl after 24 hours but after $48 \mathrm{~h}$ the toxicity was reduced at all concentrations except $0.04 \mu \mathrm{mol} / \mathrm{L}$ compared to the baseline test. The sodium thiosulphate addition increased the observed toxicity at lower concentrations of TBT-Cl. Only at the top TBT-Cl concentration was the toxicity observed to be less than the baseline. Passage through the $\mathrm{C}_{18}$ column removed toxicity at all concentrations, which is indicative of organic compounds 
being responsible for the observed toxicity in the initial and baseline tests. Table 6 shows the $\mathrm{EC}_{50}$ values and corresponding NOEC and LOEC values for all manipulations. Little information was available in the literature on the sensitivity of the test species to the reagents used in the manipulations (e.g. EDTA, $\mathrm{Na}_{2} \mathrm{~S}_{2} \mathrm{O}_{3}$ ) therefore blanks were run alongside all manipulations. Ethylenediaminetetraacetic acid was shown to be significantly toxic to $V$. fischeri at the top concentration in the Basic Microtox ${ }^{\circledR}$ test but was not at all toxic to T. battagliai. Sodium thiosulphate was not observed to be toxic to $V$. fischeri but significantly increased the toxicity of the TBT-Cl to $T$. battalgliai when added suggesting a possible synergistic effect (Figure 4). 


\section{Discussion}

Persistent Organic Pollutants (POPs) are widespread contaminants in the marine environment and represent a global problem. They encompass many different groups of chemicals including PAHs, PCBs and organotins and are of the utmost concern in marine environmental evaluation and risk assessment. In environmental testing, bioassays should be employed in tandem with traditional chemical analysis to provide an integrated picture of the overall toxicity of the various exposure phases (i.e. porewater, elutriate, solvent extracts, whole sediment) from a contaminated site. There is no universally sensitive test species that can reliably predict the potential hazards associated with contaminated sediments. A multi-trophic battery of tests, which incorporates a number of test species and a variety of endpoints (e.g. lethality, growth inhibition) is therefore advocated to reduce the probability of false negative results. In this study the sensitivities of a battery of bioassays containing an indigenous Irish alga and crustacean, to a suite of organic contaminants were investigated. The selected tests have the advantage of being inexpensive, reproducible, easy to conduct and ecologically relevant.

The Microtox ${ }^{\circledR}$ assay with the bioluminescent bacteria $V$. fischeri represents the decomposer echelon in the multi-trophic battery of tests. It has long been considered an extremely sensitive test system and in several recent studies it has proven to be the most sensitive assay employed as part of a battery approach (Davoren and Fogarty, 2004; Jos et al., 2005). In the current study however, it was not found to be the most sensitive test system employed. The benthic harpacticoid copepod T. battagliai was several orders of magnitude more sensitive to the PAHs and PCBs and also more sensitive than the Microtox ${ }^{\circledR}$ system to the organotin TPT. 
Tests with the Microtox ${ }^{\circledR}$ system and TBT-Cl and TPT-Cl resulted in 15 min $\mathrm{EC}_{50}$ values of 0.083 and $0.250 \mu \mathrm{mol} / \mathrm{L}$ respectively, in this research. Fifteen minute $\mathrm{EC}_{50}$ values of 0.029 and $0.052 \mu \mathrm{mol} / \mathrm{L}$ have been previously reported (Argese et al.,1998) for TBT-Cl and TPT-Cl respectively. Several other authors have reported similar $\mathrm{EC}_{50}$ values after $15 \mathrm{~min}$ exposure to TBT: $0.03 \mu \mathrm{mol} / \mathrm{L}(0.011 \mathrm{mg} / \mathrm{L})$ [Fernández-Alba et al., 2002], $0.76 \mu \mathrm{mol} / \mathrm{L}(246.8 \mu \mathrm{g} / \mathrm{L})$ [Dooley and Denis, 1987]. In this study the toxicity of both TBT-Cl and TPT-Cl were observed to increase with time. This phenomenon has previously been observed with organotins. Stasinakis et al. (2001) noted an increase in inhibition of respiration rate of activated sludge heterotrophic micro-organisms with increasing exposure time to tributyltin, dibutyltin and triphenyltin. Current work in our laboratory has also revealed increasing toxicity of TBT-Cl and TPT-Cl with increasing exposure time when examining the cytotoxic effects on the rainbow trout gonad (RTG-2) cell line (Giltrap et al. [in preparation]). A review article by Salizzato et al., (1996) indicated that a 5 min $\mathrm{EC}_{50}$ value is adequate to report for organic compounds. This study does not agree with this observation as toxicity for the organotins was observed to increase with lengthened exposure times. In contrast the toxicity of the PAHs to Microtox ${ }^{\circledR}$ in this study was observed to decrease with exposure time. In this study a 15 min $\mathrm{EC}_{50}$ value of 17.57 $\mu \mathrm{mol} / \mathrm{L}$ was reported for fluoranthene. El-Alawi et al., (2002) reported a similar 15 $\min \mathrm{EC}_{50}$ value of $2.16 \mathrm{mg} / \mathrm{L}(10.67 \mu \mathrm{mol} / \mathrm{L})$. No toxicity data for PCB 153 were found in the literature for the acute Microtox $^{\circledR}$ assay.

After an extensive search of the literature no toxicity data was found for $T$. battagliai and the organotins. However, Alzieu (1996) revealed that significant effects on the growth and reproduction of phytoplankton and zooplankton have been observed at concentrations of less than $0.4 \mu \mathrm{g} / \mathrm{L}$ of TBT $(0.001 \mu \mathrm{mol} / \mathrm{L})$. In this study 
$24 \mathrm{~h}$ and $48 \mathrm{~h} \mathrm{LC} 50$ values were reported for both TBT-Cl and TPT-Cl (Table 4). Forty eight hour $\mathrm{LC}_{50}$ values of $0.068 \mu \mathrm{mol} / \mathrm{L}$ and $0.009 \mu \mathrm{mol} / \mathrm{L}$ were recorded for TBT-Cl and TPT-Cl respectively. Kusk and Peterson (1997) reported a 48-h $\mathrm{LC}_{50}$ of $0.0007 \mu \mathrm{mol} / \mathrm{L}$ TBT for the calanoid copepod Acartia tonsa. The next most toxic compound to T. battagliai was PCB 153 with $24 \mathrm{~h}$ and $48 \mathrm{~h} \mathrm{LC} \mathrm{L}_{50}$ values of 0.834 $\mu \mathrm{mol} / \mathrm{L}$ and $0.357 \mu \mathrm{mol} / \mathrm{L}$ respectively. Barata et al., (2002) conducted a $96 \mathrm{~h}$ acute toxicity test with fluoranthene and reported an $\mathrm{LC}_{50}$ value of $0.310 \mu \mathrm{mol} / \mathrm{L}(0.063$ $\mathrm{mg} / \mathrm{L})$. In this study only $24 \mathrm{~h}$ and $48 \mathrm{~h} \mathrm{LC}_{50}$ values of $3.211 \mu \mathrm{mol} / \mathrm{L}$ and 1.193 $\mu \mathrm{mol} / \mathrm{L}$ respectively were observed for fluoranthene. Benzo[a]pyrene, a known carcinogen proved to be the least toxic of the five organics to $T$. battagliai. It is important at this stage to point out that all testing with $\mathrm{B}[\mathrm{a}] \mathrm{P}$ was conducted without metabolic activation. Benzo[a]pyrene is chemically unreactive, but during its metabolic processing by the cell, the parent compound can be activated to electrophilic derivatives, which bind covalently to nucleophilic residues in cellular macromolecules, rendering them more toxic (Miller and Whitlock, 1981).

The importance of copepods to the marine ecosystem cannot be over emphasised. The abundant calanoid and cyclopoid copepods of the plankton form the first vital link in the food chain that leads from the microscopic algal cells of the phytoplankton up to the larger fish and mammals. These phytoplankton-feeding copepods are undoubtedly the most important primary consumers in marine planktonic communities and, as such, form the base of virtually all pelagic food chains. Therefore, the sensitivity of these ubiquitous organisms to commonly occurring organic contaminants such as the organotins is of the highest consequence to the effective functioning of the marine ecosystem. 
The ecotoxicology of the organotins has been of major concern in the past few decades and information available on the subject is essentially related to triorganotins (TBT, TPT). Trialkyltins are oxidative phosphorylation inhibitors and the nature of the alkyl group determines the degree of the toxic effect on different species. In this study the organotin compounds (TBT-Cl and TPT-Cl) were consistently the most toxic chemicals to all species. The phenyltin was more toxic than the butyltin in the case of T. battagliai and the prasinophyte $T$. suecica, while TBT was the more toxic in the Microtox ${ }^{\circledR}$ assay. Data available on the effects of butyltins and organotin derivatives other than TBT on aquatic marine organisms are scarce. Measurements of TBT and other organotin concentrations in waters and sediments from harbours and estuaries globally have shown a reduction in contamination compared to that observed in the early 1980s. This is due in part to the legislation and shipping restrictions that have been introduced in recent years to curtail the use of organotin containing marine antifoulant paints. The degradation of organotins in waters is short (half life is $6-7$ days at $28{ }^{\circ} \mathrm{C}$ for estuarine waters, up to 17 days for open ocean waters [Batley, 1996]), while oxic surface sediments are microbially mediated and persistence differs little from half lives in water. However, in deeper anoxic sediments, degradation is significantly slower with half lives of 1.9 to 3.8 years (Batley, 1996) which may lead to detrimental effects should the biota become exposed following dredging of the sediments. Therefore there is a need for further evaluation of these compounds for a large number of species to allow for probable thresholds ensuring survival and reproduction of the organisms within an ecosystem especially where dredging is likely (e.g. harbours, estuaries).

Polycyclic aromatic hydrocarbon (PAH) toxicity is structurally dependent (Kalf et al., 1997). Fluoranthene, a four-ringed PAH, is one of the most abundant 
$\mathrm{PAH}$ contaminants in the environment. Fluoranthene, a four-ringed $\mathrm{PAH}$, is one of the most abundant PAH contaminants in the environment. For this reason and because PAHs are on the OSPAR List of Substances for Priority Action, fluoranthene was chosen for inclusion in this study. Despite its abundant presence in the environment there is very little information available on its toxic effects on marine species. Most PAHs are indirect acting toxicants and require metabolic activation to elicit a toxic effect on the test organism. In this study benzo[a]pyrene was observed to be highly toxic to $T$. battagliai but was considerably less toxic to V. fischeri. Although it is a well known carcinogen, the metabolic derivatives of $\mathrm{B}[\mathrm{a}] \mathrm{P}$ have been observed to be far more toxic than the parent compound itself (Araújo et al., 2000). The toxicity of these metabolic products was not investigated in this study.

While a number of other PCB congeners are known to be of greater toxicity, PCB 153 was chosen for inclusion in this study as it is a persistent, routinely monitored congener in marine sediments in Ireland. The results indicate that the PCB is highly toxic to T. battagliai. It was found to be more toxic to the copepod than the two PAHs but not as toxic as the organotins. Despite various studies on PCBs, their mechanism of toxicity is still unknown. It was not possible to derive $\mathrm{EC}_{50}$ values for the Microtox ${ }^{\circledR}$ and algal tests in this study. Stock concentration of PCB 153 were prepared and tested on the same day with the Microtox ${ }^{\circledR}$ system and algae. To avoid analytical interference from plastics, glassware was used in preparation of chemicals and the use of plastics was kept to a minimum. Initial testing with $V$. fischeri yielded a dose response curve. High toxicity, in excess of $50 \%$ effect, was observed after 5 min exposure after which toxicity was observed to decrease with time to as low as 37 $\%$ after $30 \mathrm{~min}$ at the top concentration $(62 \mu \mathrm{mol} / \mathrm{L})$. Subsequent toxicity testing with other stock solutions of PCB after storage (in a glass volumetric flask at $4{ }^{\circ} \mathrm{C}$ in the 
dark for $>24 \mathrm{~h}$ ) demonstrated little or no toxicity. After several definitive tests with PCB 153 and $T$. suecica the results were not found to be reproducible. Stock solutions were made up on several occasions, tested, stored and retested, and the same effect was observed. Lung et al. (2000) investigated adsorption/desorption of PCB congeners in aqueous solution onto glass surfaces. They found that adsorption loss is related to the degree of chlorination of the PCB congener. In their study PCB 180 (isomer group Cl-7) showed the greatest absorbance (55\%) onto the glass surface and PCB 52 (Cl-4) lost the least (17\%). Lung et al. (2000) also concluded that PCB congeners may adsorb more onto glass surfaces in saline water due to a 'salting out effect' i.e. hydrophobic PCBs are less soluble in more polar aqueous environments. Such effects may partly explain the reduction in toxicity observed in the Microtox ${ }^{\circledR}$ and algal tests after storage of the stock PCB 153 (Cl-6). The inconsistent results observed with the algal tests (conducted in glass Erlenmeyer flasks) may also be partially explained by the 'salting out effect' described by Lung et al. Recently Breitholtz et al., (2007) published a method for overcoming the difficulties of testing poorly water-soluble substances using a silica gel test system. They concluded that the system enables a more controlled exposure of hydrophobic substances that traditional water test systems since the concentration-response relationship becomes distinct and there is no carrier solvent. These methods are only in the early stages of development but may allow for a more accurate screening of hydrophobic substances for risk assessment with substances such as those employed in this study.

One of the main objectives of this research was to identify a suitable test species for employment in Toxicity Identification Evaluation (TIE) with sediment porewaters of suspected toxicity in routine assessment and monitoring of Irish sediments. Toxicity Identification Evaluation methods in marine risk assessment and 
environmental evaluation have been employed in the United States for many years (Burgess et al., 1995; Burgess et al., 1996). A few studies with marine porewaters exist for European waters (Guzzella et al., 1996). Toxicity Identification Evaluation techniques, using bioassays to direct the fractionation of complex environmental samples (e.g. sediment porewater) can be applied in an attempt to identify the compounds responsible for any observed toxicity of the sample. When conducting TIE manipulations, both acute and chronic endpoints with several different species would ideally be used. This is not always feasible. The problems associated with porewater sample extraction (particularly when sandy sediments with a high proportion of $>2 \mathrm{~mm}$ particles are being investigated) can be prohibitive in employing tests that necessitate large volumes of test solution e.g. traditional microalgal flask methods. The Microtox ${ }^{\circledR}$ acute assay would be considered an ideal candidate for TIE based on the small sample volume required and the speed of testing $(5,15,30 \mathrm{~min})$. However, although the Microtox ${ }^{\circledR}$ assay was highly sensitive to the organotins it demonstrated poor sensitivity to the PAHs and PCB compared to $T$. battaglia. Although the T. battagliai test requires larger sample volumes and is of longer duration than the Microtox ${ }^{\circledR}$ test, it is considered suitable because of its greater sensitivity to a wider range of chemicals. The spiked sample manipulations conducted with the Microtox ${ }^{\circledR}$ and T. battalgiai acute toxicity test systems verified their suitability as test species for TIE studies. With both species it was possible to conduct all manipulations within one day. In the case of the Microtox ${ }^{\circledR}$ system all manipulations could be conducted in triplicate within three days while for $T$. battagliai it was possible to do so within one week, depending on the numbers of organisms available in culture. Results from these TIEs on simple spiked samples 
provide insight into the complexity of interpreting marine TIE data from porewater studies where mixtures of unknown substances are present. 


\section{Conclusion}

In conclusion, all organic compounds tested elicited a toxic effect on all species employed. The concentrations tested include environmentally relevant levels previously identified in the water column (e.g. Organotins: Batley, 1996).

The Microtox ${ }^{\circledR}$ assay demonstrated high sensitivity to the organotin compounds but not the PAHs. The algal growth inhibition assays and the copepod lethality test were found to be the most sensitive of the battery tests to all chemicals. The microalgae, a primary producer and T. battagliai, a primary consumer can be considered essential components of the marine food web and are indigenous Irish species, lending ecological relevance to this study. Although the algae were found to be more sensitive to several of the organic contaminants assayed the copepod bioassay was selected as the most suitable species for use in future TIE studies with marine sediments. The demonstrated sensitivity of the copepods to all chemicals tested coupled with the assays' rapid and simple features make it the most suitable candidate for TIE manipulations. In general there is a paucity of ecotoxicological data for marine species and organic contaminants and especially with respect to an Irish marine context. The data presented in this report have for the most part not previously been reported in the literature. Therefore, the data described may aid in future management decisions and contribute to the new efforts being made within the EU through programmes such as REACH (Registration, Evaluation and Authorisation of Chemicals). Thus information such as that outlined in this paper can confer greater responsibility on industry in the management of the risks associated with chemical usage and disposal. 


\section{Acknowledgements}

We sincerely wish to thank the Shannon Aquatic Toxicological Laboratory (SATL), especially Robert Hernan and Kathleen O'Rourke, for supplying the Tisbe battagliai and providing technical assistance for starting up our own culture facility.

Funding for this research was provided by Technology Sector Research: Strand III: Core Research Strengths. 


\section{References}

Alzieu, C., 1996. Biological effects of tributlytin on marine organisms. In: de Mora, S.J. (Ed.), Tributyltin: A case study. Cambridge University Press, pp. 167-211.

Anon., 1987. Restrictions of use of organotin antifouling compounds. Bye-Law No. 657. Stationary Office, Dublin.

Argese, E., Bettiol, C., Volpi Ghirardini, A., Fasolo, M., Giurin, G., Ghetti, P.F., 1998. Comparison of in vitro submitochondrial particle and Microtox $^{\circledR}$ assays for determining the toxicity of organotin compounds. Environmental Toxicology and Chemistry 17, 1005-1012.

Araújo, C.S.A., Marques, S.A.F., Carrondo, M.J.T., Gonçalves, L.M.D., 2000. In vitro response of the brown bullhead catfish (BB) and rainbow trout (RTG-2) cell lines to benzo[a]pyrene. Science of the Total Environment 247, 127-135.

Azur Environmental Ltd., 1998. Microtox ${ }^{\circledR}$ acute toxicity basic test procedures. Carlsbad, CA, USA.

Barata, C., Baird, D.J., Medina, M., Albalat, A., Soares, A., 2002. Determining the ecotoxicological mode of action of toxic chemicals in meiobenthic marine organisms: stage-specific short tests with Tisbe battagliai. Marine Ecology Progress Series 230, 183-194. 
Batley, G.I. 1996. The distribution and fate of tributyltin in the marine environment. In: Mora SJ (Ed.) Tributyltin: Case study of an environmental contaminant. Cambridge University Press, Cambridge, pp. 139-166.

Bechmann, R.K. 1999. Effects of the endocrine disrupter nonylphenol on the marine copepod Tisbe battagliai. Science of the Total Environment 233, 33-46.

Breitholtz, M., Ricklund, N., Bengtsson, B-E., Persson. 2007. Silica gel as a particulate carrier of poorly water-soluble substances in aquatic toxicity testing. Aquatic Toxicology 82, 251-264.

Bryan, G.W., Gibbs, P.E., Hummerstone, L.G., Burt, G.R., 1986. The decline of the gastropod Nucella lapillus around south-west England: Evidence for the effect of tributyltin from antifouling paints. Journal of the Marine Biological Association UK 66, 611-640.

BS EN ISO 10253, 1998. Water Quality- Marine Algal growth inhibition test with Skeletonema costatum and Phaeodactylum tricornutum. London, The British Standards Institute.

Burgess, R.M., Ho, K.T., Tagliabue, M.D., Kuhn, A., Comeleo, R., Comeleo, P., Modica, G., Morrison, G.E., 1995. Toxicity characterization of an industrial and a municipal effluent discharging into the marine environment. Marine Pollution Bulletin 30, 524-535. 
Burgess, R.M., Ho, K.T., Morrison, G.E., Chapman, G., D.L. Denton. 1996. Marine toxicity identification evaluation (TIE). Phase I guidance document, EPA/600/R96/054. Environmental Protection Agency, Washington, DC, USA.

Burton, G.A., 1991. Assessing the toxicity of freshwater sediments. Environmental Toxicology and Chemistry 10, 1585-1627.

Chiou, C.T., McGroddy, S.E., Kile, D.E., 1998. Partition characteristics of polycyclic aromatic hydrocarbons on soils and sediments. Environmental Science and Technology 32, 264-269.

Cronin, M., McGovern, E., McMahon, T., Boelens, R., 2006. Guidelines for the assessment of dredge material for disposal in Irish waters. Marine Environmental and Health Series, No. 24. Marine Institute, Galway, Ireland.

Davoren, M. and Fogarty, A.M., 2004. A test battery for the ecotoxicological evaluation of the agri-chemical Environ. Ecotoxicology and Environmental Safety 59, 116-122.

Davoren, M., Ní Shúilleabháin, S., Hartl, M.G.J., Sheehan, D., O’Brien, N.M. O’ Halloran, J., Van Pelt, F.N.A.M., Mothersill C., 2005. A test battery approach for the ecotoxicological evaluation of estuarine sediments. Ecotoxicology. 65, 332-341. 
Dooley, C.A., Denis, P., 1987. Response of bioluminescent bacteria to alkyltin compounds. Proceedings of the Organotin Symposium., Oceans '87 Conference, 28 September - 1 October 1987, Halifax, Nova Scotia. 4, 1514-1524.

El-Alawi, Y., Huang, X-D., Dixon, D.G., Greenberg, B.M., 2002. Quantitative structure-activity relationship for the photoinduced toxicity of polycyclic aromatic hydrocarbons to the luminescent bacteria Vibrio fischeri. Environmental Toxicology and Chemistry 21, 2225-2232.

Fernández-Alba, A.R., Hernando, M.D., Piedra, L., Chisti, Y., 2002. Toxicity evaluation of single and mixed antifouling biocides measured with acute toxicity bioassays. Analytica Chimica Acta 456, 303-312.

Guzzella, L., Bartone, C., Ross, P., Tartari, G. Muntau, H., 1996. Toxicity identification evaluation of Lake Orta (Northern Italy) sediments using microtox system. Ecotoxicology and Environmental Safety 35, 231-235.

Hernando, M.D., Ejerhoon, M., Fernánez-Alba, A.R., Chisti, Y., 2003. Combined toxicity effects of MTBE and pesticides measured with Vibrio fischeri and Daphnia magna bioassays. Water Research 37, 4091-4098.

Horiguchi, T., Shiraishi, H., Shimizu, M., Morita, M., 1997. Effects of triphenyltin chloride and five other organotin compounds on the development of imposex in the rock shell, Thais clavigera. Environmental Pollution 95, 85-91. 
Hutchinson, T.H., Williams, T.D., Eales. G.J. 1994. Toxicity of cadmium, hexavalent chromium and copper to marine fish larvae (Cyprinodon variegates) and copepods (Tisbe battagliai). Marine Environmental Research 38, 275-290.

Ingersoll, C.G. 2003. Sediment Tests. In: Rand GM (Ed.) Fundamentals of aquatic toxicology: Effects, environmental Fate and Risk Assessment., pp. 231-256.

ISO/DIS 14669, 1997. Water Quality - Determination of acute lethal toxicity to marine copepoda (Copepoda, Crustacea). Geneva, Switzerland, International Standard.

Jos, A., Repetto, G., Rios, J.C., del Peso, A., Salguero, M., Hazen, M.J., Molero, M.L., Fernández-Freire, P., Pérez-Martín, J.M., Labrador, V, Cameán, A., 2005. Ecotoxicological evaluation of the additive butylated hydroxyanisole using a battery with six model systems and eighteen endpoints. Aquatic Toxicology 71, 183-192.

Kalf, D.F., Crommentuijn, T., van de Plassche, E.J., 1997. Environmental quality objectives for 10 polyaromatic hydrocarbons (PAHs). Ecotoxicology and Environmental Safety 36, 89-97.

Kilemade, M., Hartl, M.G.J., Sheehan, D., Mothersill, C., van Pelt, F.N.A.M., O'Brien, N.M., O'Halloran, J. 2004. An Assessment of the pollutant status of surfical sediment in Cork Harbour in the South East of Ireland with particular reference to polycyclic aromatic hydrocarbons. Marine Pollution Bulletin 49, 1084-1096. 
Kusk K.O., Petersen, S. 1997. Acute and chronic toxicity of tributyltin and linear alkylbenzene sulfonate to the marine copepod Acartia tonsa. Environmental Toxicology and Chemistry 16, 1629-1633.

Kwan, K.K., Dutka, B.J., 1990. Simple two-step sediment extraction procedure for use in genotoxicity and toxicity bioassays. Toxicity Assessment 5, 395-404.

Leonards, P.E.G., Zierikzee, Y., Brinkman, U.A.T., Cofino, W.P., Van Straalen, N.M., Van Hattum, B., 1997. The selective dietary accumulation of planar polychlorinated biphenyls in otter (Lutra lutra). Environmental Toxicology and Chemistry 16, 1807-1815.

Lung S-C., Altshul, L.M., Ford, T.E., Sengler, J.D. 2000. Coating effects on the glass adsorption of polychlorinated biphenyl (PCB) congeners. Chemosphere 41, 18651871

Miller, A.G., Whitlock, J.P., 1981. Novel variants in Benzo[a]pyrene metabolism isolation by fluorescence-activated cell sorting. Journal of Biological Chemistry 256 (5), 2433-2437.

Minchin, D., Stroben, E., Oehlmann, J., Bauer, B., Duggan, C.B., Keatinge, M., 1996. Biological indicators used to map organotin contamination in Cork Harbour, Ireland. Marine Pollution Bulletin 32, 188-195. 
Ockenden, W.A., Sweetman, A.J., Prest, H.F., Steinnes, E., Jones, K.C., 1998. Towards an understanding of the global atmospheric distribution of persistent organic pollutants: The use of semipermeable membrance devices as time-integrated passive samplers. Environmental Science and Technology 32, 2795-2803.

Salizzato. M., Rigoni, M., Pavoni, B., Volpi Ghirardini, A., Ghetti, P.F. 1996. Separation and quantification of organic micropollutants (PAH, PCB) in sediments. Toxicity of extracts towards Vibrio fischeri. Toxicological and Environmental Chemistry 60, 183-200.

Stasinakis, A.S., Thomaidis, N.S., Lekkas, T.D., 2001. Toxicity of organotin compounds to activated sludge. Ecotoxicology and Environmental Safety 49, 275-280.

Ten Hallers-Tjabbes, C.C., Wegener J.W., Van Hattum B.A., Kemp J.F., Ten Hallers E., Reitsemae, T.J., 2003. Imposex and organotin concentrations in Buccinum undatum and Neptunea antiqua from the North Sea: relationship to shipping density and hydrographical conditions. Marine Environmental Research 55, 203-233.

Tolun, L. G., Okay, O.S., Gaines, A.F., Tolay, M., Tüfekçi, H., Kirath, N., 2001. The pollution status and the toxicity of surface sediments in Izmit Bay (Maramara Sea), Turkey. Environment International 26, 163-168.

Utgikar, V. P., Chaudhary, N., Koeniger, A., Tabak, H.H., Haines, J.R., Govind, R., 2004. Toxicity of metals and metal mixtures: analysis of concentration and time dependence for zinc and copper. Water Research 38, 3651-3658. 
Vindimian, E. REGTOX-EV6.xls. Regtox 6.3 software program. Xls (http://eric.vindimian.9online.fr). 
Table 1

\begin{tabular}{|c|c|c|c|c|c|c|}
\hline $\begin{array}{l}\text { Trophic } \\
\text { level }\end{array}$ & Test Species & Chemical & $\begin{array}{l}\text { Exposure } \\
\text { Time } \\
\end{array}$ & Endpoint & Toxicity value & Reference \\
\hline \multirow{6}{*}{ Bacteria } & & TBT-Cl & $15 \mathrm{~min}$ & $\mathrm{EC}_{50}$ & $0.029 \mu \mathrm{mol} / \mathrm{L}$ & Argese et al.,1998 \\
\hline & & TBT-Cl & $5 \mathrm{~min}$ & $\mathrm{EC}_{50}$ & $0.022 \mathrm{mg} / \mathrm{L}$ & Fernández-Alba et al., 2002 \\
\hline & & TBT-Cl & $15 \mathrm{~min}$ & $\mathrm{EC}_{50}$ & $0.011 \mathrm{mg} / \mathrm{L}$ & Fernández-Alba et al., 2002 \\
\hline & & TBT-Cl & $5 \min$ & $\mathrm{EC}_{50}$ & $7.0 \mu \mathrm{g} / \mathrm{L}$ & Dooley and Denis, 1987 \\
\hline & & FLA & $18 \mathrm{~h}$ & $\mathrm{EC}_{50}$ & $80.99 \mathrm{mg} / \mathrm{L}$ & El Alawi et al., 2002 \\
\hline & & TBT & $30 \min$ & $\mathrm{EC}_{50}$ & $0.007 \pm 0.0012 \mathrm{mg} / \mathrm{L}$ & Hernando et al., 2003 \\
\hline \multirow[t]{2}{*}{ Copepods } & Tisbe battagliai & Acetone & $26 \mathrm{~d}$ & NR & $25 \mu \mathrm{l} / \mathrm{L}$ & Bechmann, 1999 \\
\hline & Tisbe battagliai & FLA & $4 \mathrm{~d}$ & $\mathrm{LC}_{50}$ & $0.063 \mathrm{mg} / \mathrm{L}$ & Barata et al., 2002 \\
\hline
\end{tabular}

DMSO = Dimethyl sulphoxide, NR = Not Reported, MAC $=$ Maximum Allowable Concentration, FLA $=$ Fluoranthene, EC $_{50}=$ Effective Concentration of $50 \%$ of sample population, $\mathrm{LC}_{50}=$ Lethal concentration of $50 \%$ of sample population. 
Table 2

\begin{tabular}{llllll}
\hline Species & $\begin{array}{l}\text { Reference } \\
\text { chemical }\end{array}$ & $\begin{array}{l}\text { Exposure period and endpoint } \\
\end{array}$ & $\begin{array}{l}\text { EC/LC } \mathbf{5 0}^{\mathbf{a}} \\
(\mathbf{m g} / \mathbf{L})\end{array}$ & $\begin{array}{l}\text { Cited } \\
\text { value } \\
(\mathbf{m g} / \mathbf{L})\end{array}$ & $\begin{array}{l}\text { Reference } \\
\end{array}$ \\
\hline Vibrio fischeri & $\mathrm{C}_{6} \mathrm{H}_{6} \mathrm{O}$ & 5 min inhibition & $21.29(14.73-35.26)$ & $13-26$ & Azur Environmental (1998) \\
Tetraselmis suecica & $\mathrm{K}_{2} \mathrm{Cr}_{2} \mathrm{O}_{7}$ & 72 h inhibition & $14.12(11.20-15.13)$ & - & \\
Tisbe battagliai & $\mathrm{K}_{2} \mathrm{Cr}_{2} \mathrm{O}_{7}$ & 48 h lethality & $7.42(5.73-10.01)$ & $1.6^{\mathrm{b}}$ & Hutchinson et al. (1994) \\
& & & & $5.9^{c}$ & Hutchinson et al. (1994) \\
\hline
\end{tabular}

${ }^{\mathrm{a}} \mathrm{EC}_{50}$ values and corresponding $95 \%$ confidence intervals in parentheses

${ }^{\mathrm{b}} 96 \mathrm{~h} \mathrm{LC}_{50}$ value for nauplii

${ }^{\mathrm{c}} 96 \mathrm{~h} \mathrm{LC}_{50}$ value for adult females 
Table 3 .

\begin{tabular}{|c|c|c|c|c|c|}
\hline Test chemical & Exposure time (min) & $\begin{array}{l}\text { Concentration range } \\
(\mu \mathrm{mol} / \mathrm{L})\end{array}$ & $\mathrm{EC}_{50}{ }^{\mathrm{a}}(\mu \mathrm{mol} / \mathrm{L})$ & $\operatorname{NOEC}(\mu \mathrm{mol} / \mathrm{L})^{\mathrm{b}}$ & $\mathrm{LOEC}(\mu \mathrm{mol} / \mathrm{L})^{\mathrm{c}}$ \\
\hline \multirow[t]{2}{*}{ TBT-Cl } & 5 & $0.004-0.900$ & $0.129(0.124-0.224)$ & 0.056 & 0.113 \\
\hline & 30 & $0.004-0.900$ & $0.059(0.055-0.080)$ & 0.028 & 0.056 \\
\hline \multirow[t]{2}{*}{ TPT-Cl } & 5 & $0.004-0.900$ & $0.584(0.400-0.802)$ & 0.225 & 0.450 \\
\hline & 30 & $0.004-0.900$ & $0.184(0.103-0.247)$ & 0.113 & 0.225 \\
\hline \multirow[t]{3}{*}{$\mathrm{B}[\mathrm{a}] \mathrm{P}$} & 5 & $0.588-150.740$ & $70.026(55.821-85.755)$ & 9.421 & 18.843 \\
\hline & 15 & $0.588-150.740$ & $154.071(121.721-202.150)^{\mathrm{d}}$ & 18.843 & 37.685 \\
\hline & 30 & $0.588-150.740$ & $230.777(143.996-832.610)^{\mathrm{d}}$ & 75.370 & 150.740 \\
\hline
\end{tabular}

${ }^{\mathrm{a}} \mathrm{EC}_{50}$ values and corresponding $95 \%$ confidence intervals in parentheses

${ }^{b}$ NOEC, no observed effect concentration, the highest observed concentration at which no significant effect $(p \leq 0.05)$ was detected

${ }^{c}$ LOEC, lowest observed effect concentration, the lowest concentration of the tested concentration at which a significant $(p \leq 0.05)$ effect was detected.

${ }^{\mathrm{d}} \mathrm{EC}_{50}$ values and corresponding 95\% confidence intervals calculated by extrapolation of the data by REGTOX-EV6.xls 
Table 4

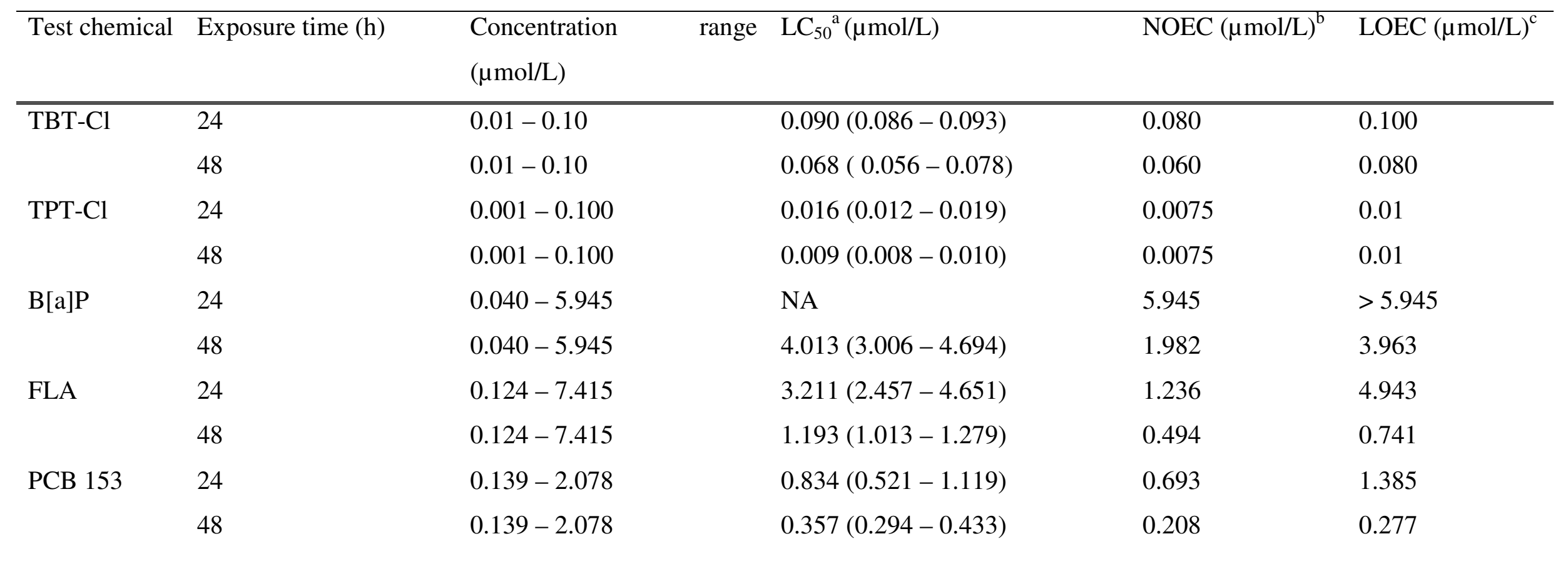

\footnotetext{
${ }^{\mathrm{a}} \mathrm{LC}_{50}$ values and corresponding $95 \%$ confidence intervals in parentheses

${ }^{b}$ NOEC, no observed effect concentration, the highest observed concentration at which no significant effect $(p \leq 0.05)$ was detected

${ }^{c}$ LOEC, lowest observed effect concentration, the lowest concentration of the tested concentration at which a significant $(p \leq 0.05)$ effect was detected.

NA $=$ Not Applicable
} 
Fig 1<smiles>[Al][Al](Br)(Br)Br</smiles>

Tributyltin chloride<smiles>c1ccc2c(c1)cc1ccc3ccc4ccc5cccc1c5c4c32</smiles>

Benzo[a]pyrene

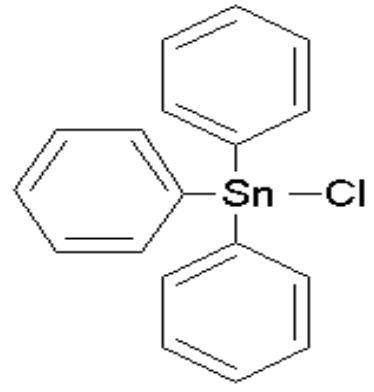

Triphenyltin chloride

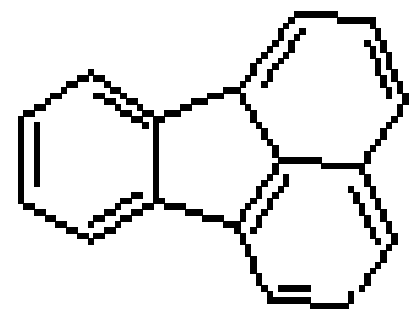

Fluoranthene<smiles>Clc1cc(Cl)c(-c2cc(Cl)c(Cl)cc2Cl)cc1Cl</smiles>

2,2',4,4',5,5' -hexachlorobiphenyl (PCB 153) 
Fig. 2

\section{Day 1:}

Initial toxicity test of sample

with battery of species

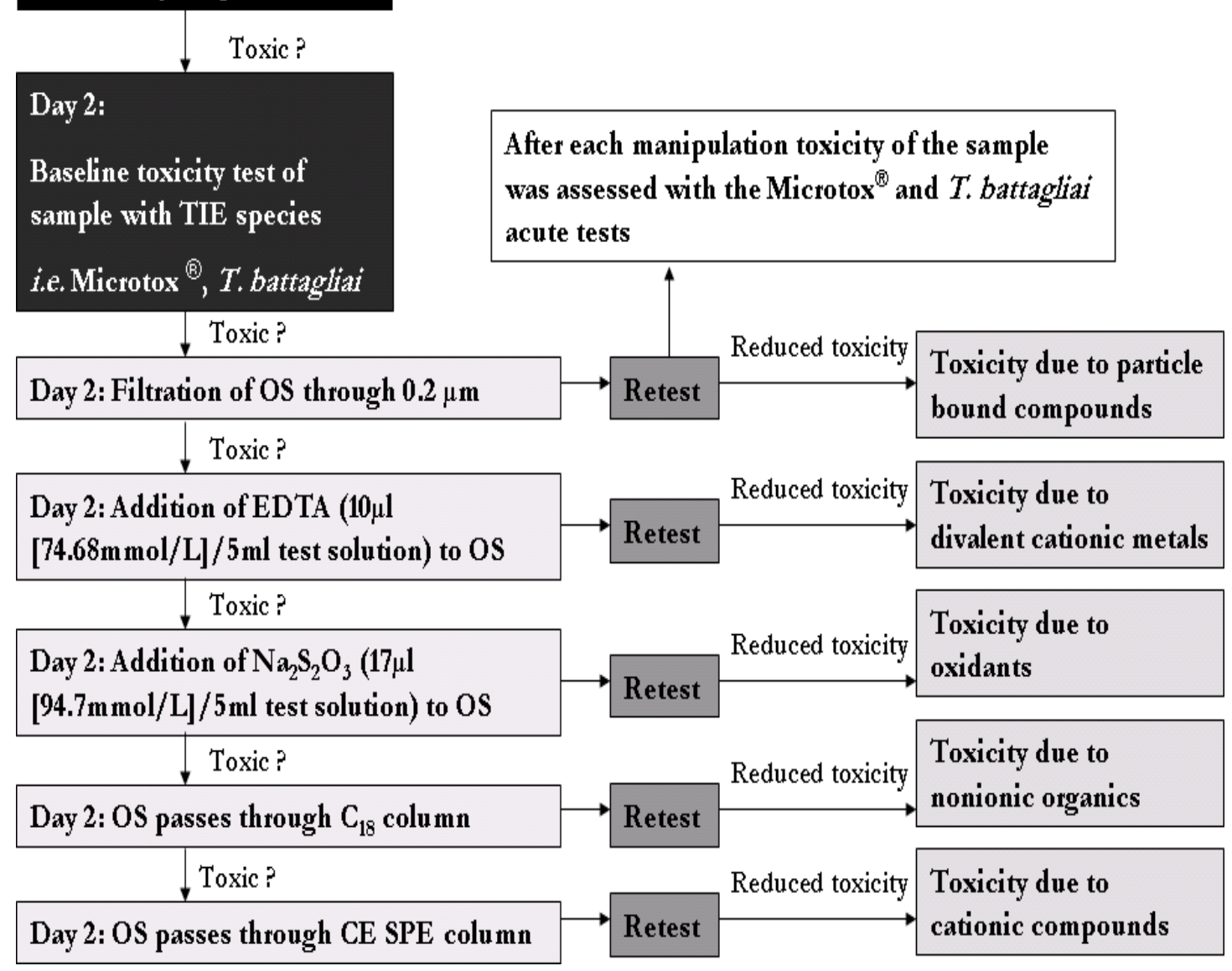


Fig. 3(a)

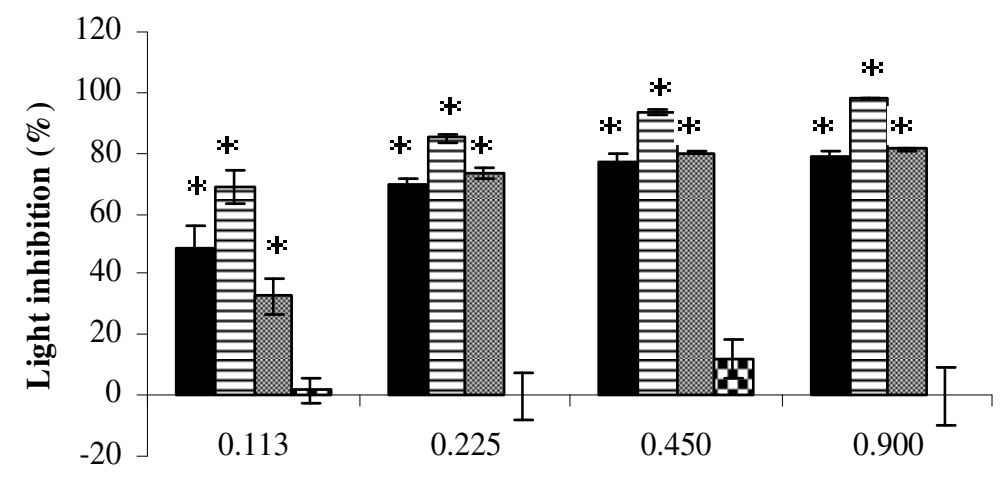

Concentration of TBT-Cl in sample $(\mu \mathrm{mol} / \mathrm{L})$

(b)

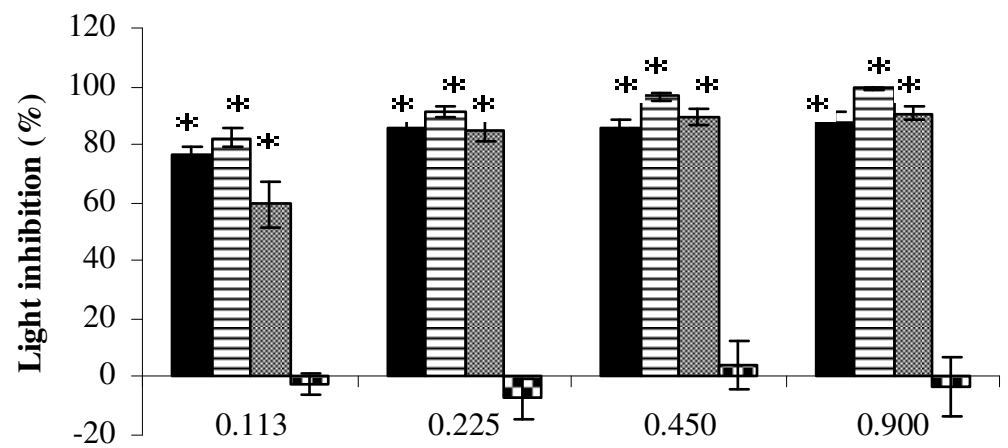

Concentration of TBT-Cl in sample $(\mu \mathrm{mol} / \mathrm{L})$

(c)

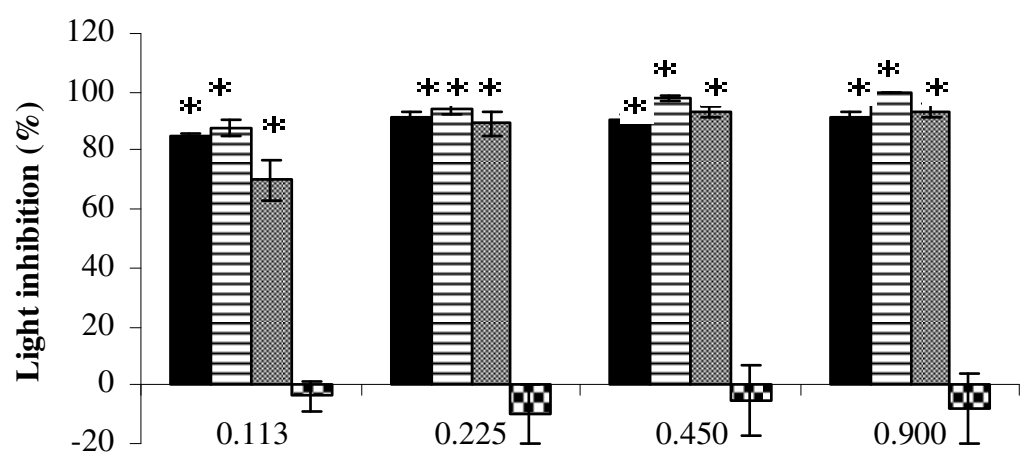

Concentration of TBT-Cl in sample $(\mu \mathrm{mol} / \mathrm{L})$ 
Fig. 4

(a)

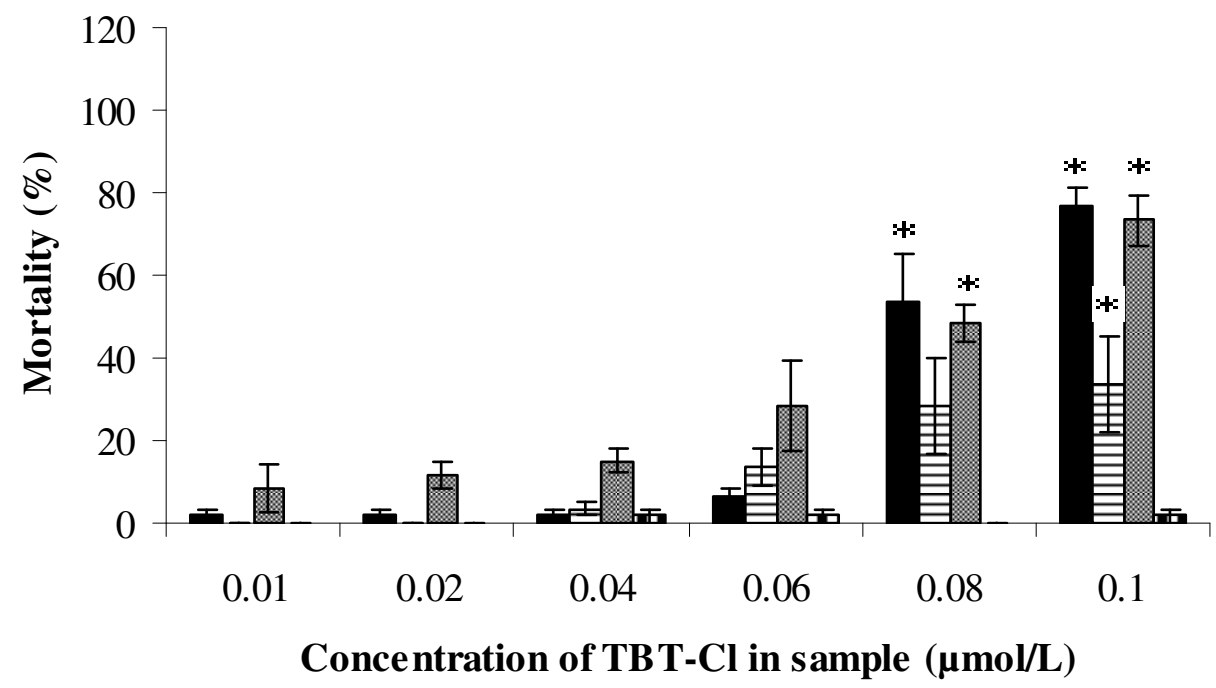

(b)

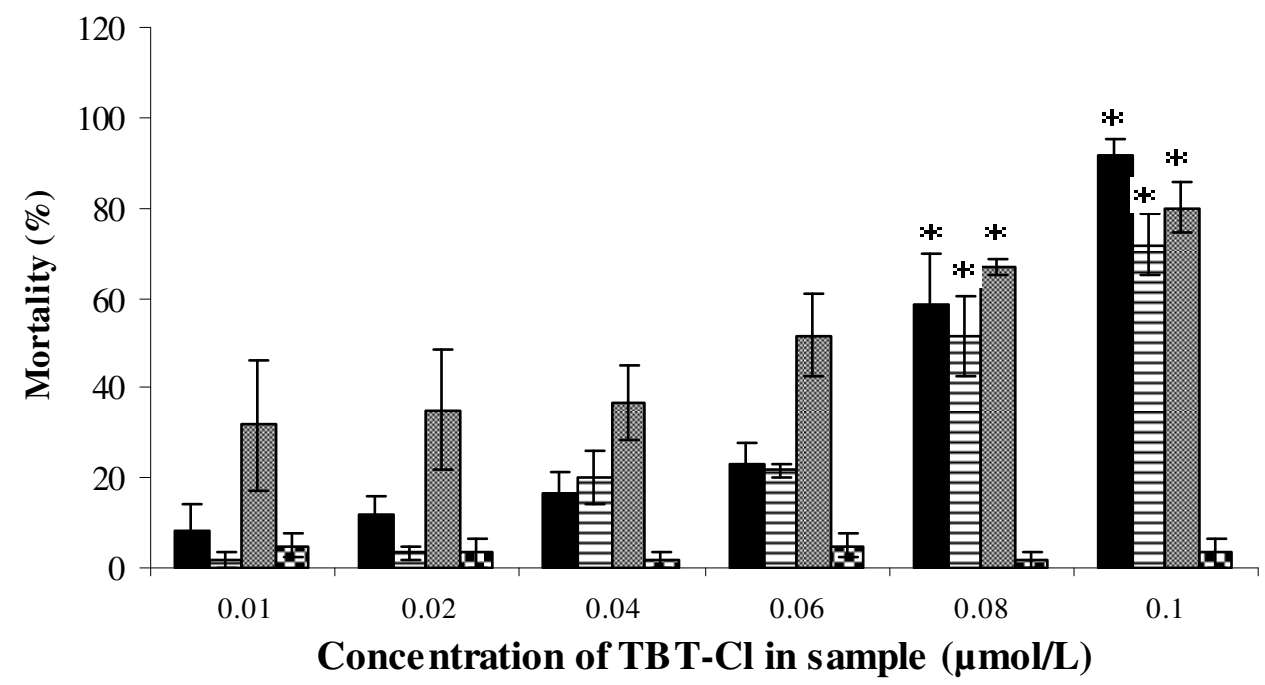


Table 5

\begin{tabular}{|c|c|c|c|c|c|c|c|}
\hline Manipulation & $\begin{array}{l}\text { Exposure } \\
\text { time (min) }\end{array}$ & $\begin{array}{l}\text { Concentration of } \\
\text { reagent stocks } \\
(\mathrm{mmol} / \mathrm{L})\end{array}$ & $\begin{array}{l}\text { Volume of reagent } \\
\text { stocks }(\mu \mathrm{l})\end{array}$ & Test type & $\mathrm{EC}_{50}(\mu \mathrm{mol} / \mathrm{L})^{\mathrm{a}}$ & $\begin{array}{l}\text { NOEC } \\
(\mu \mathrm{mol} / \mathrm{L})^{\mathrm{b}}\end{array}$ & $\begin{array}{l}\text { LOEC } \\
(\mu \mathrm{mol} / \mathrm{L})^{\mathrm{c}}\end{array}$ \\
\hline \multirow[t]{3}{*}{ Initial toxicity test } & 5 & $\mathrm{NA}^{\mathrm{d}}$ & NA & $90 \%$ test & $0.129(0.124-0.224)$ & 0.056 & 0.113 \\
\hline & 15 & NA & NA & $90 \%$ test & $0.083(0.078-0.132)$ & 0.028 & 0.056 \\
\hline & 30 & NA & NA & $90 \%$ test & $0.059(0.055-0.080)$ & 0.028 & 0.056 \\
\hline \multirow[t]{3}{*}{ Baseline test } & 5 & NA & NA & Basic test & $0.152(0.131-0.191)$ & $<0.1125$ & 0.1125 \\
\hline & 15 & NA & NA & Basic test & $0.079(0.044-0.104)$ & $<0.1125$ & 0.1125 \\
\hline & 30 & NA & NA & Basic test & $0.057(0.022-0.083)$ & $<0.1125$ & 0.1125 \\
\hline \multirow[t]{3}{*}{ EDTA addition } & 5 & 74.4 & 10 & Basic test & $0.070(0.052-0.087)$ & $<0.1125$ & 0.1125 \\
\hline & 15 & 74.4 & 10 & Basic test & $0.098(0.037-0.100)$ & $<0.1125$ & 0.1125 \\
\hline & 30 & 74.4 & 10 & Basic test & $0.027(0.009-0.050)$ & $<0.1125$ & 0.1125 \\
\hline \multirow[t]{3}{*}{$\mathrm{Na}_{2} \mathrm{~S}_{2} \mathrm{O}_{3}$ addition } & 5 & 94.9 & 17 & Basic test & $0.153(0.130-0.192)$ & $<0.1125$ & 0.1125 \\
\hline & 15 & 94.9 & 17 & Basic test & $0.079(0.042-0.104)$ & $<0.1125$ & 0.1125 \\
\hline & 30 & 94.9 & 17 & Basic test & $0.057(0.018-0.084)$ & $<0.1125$ & 0.1125 \\
\hline \multirow[t]{3}{*}{ Post $\mathrm{C}_{18}$ column } & 5 & - & - & Basic test & $\mathrm{NST}^{\mathrm{e}}$ & - & - \\
\hline & 15 & - & - & Basic test & NST & - & - \\
\hline & 30 & - & - & Basic test & NST & - & - \\
\hline
\end{tabular}

${ }^{\mathrm{a}} \mathrm{EC}_{50}$ values and corresponding $95 \%$ confidence intervals in parentheses

${ }^{\mathrm{b}}$ NOEC, no observed effect concentration, the highest observed concentration at which no significant effect $(p \leq 0.05)$ was detected

${ }^{c}$ LOEC, lowest observed effect concentration, the lowest concentration of the tested concentration at which a significant $(p \leq 0.05)$ effect was detected.

${ }^{\mathrm{d}} \mathrm{NA}$, Not Applicable

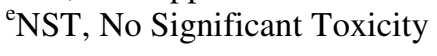


Table 6

\begin{tabular}{|c|c|c|c|c|c|c|}
\hline Manipulation & $\begin{array}{l}\text { Exposure } \\
\text { time (min) }\end{array}$ & $\begin{array}{l}\text { Concentration of } \\
\text { reagent stocks } \\
(\mathrm{mmol} / \mathrm{L}) \\
\end{array}$ & $\begin{array}{l}\text { Volume of } \\
\text { reagent stocks } \\
(\mu \mathrm{l}) \\
\end{array}$ & $\mathrm{EC}_{50}(\mu \mathrm{mol} / \mathrm{L})^{\mathrm{a}}$ & $\begin{array}{l}\text { NOEC } \\
(\mu \mathrm{mol} / \mathrm{L})^{b}\end{array}$ & $\begin{array}{l}\text { LOEC } \\
(\mu \mathrm{mol} / \mathrm{L})^{\mathrm{c}}\end{array}$ \\
\hline \multirow[t]{2}{*}{ Initial toxicity test } & $24 \mathrm{~h}$ & $\mathrm{NA}^{\mathrm{d}}$ & NA & $0.090(0.086-0.093)$ & 0.080 & 0.100 \\
\hline & $48 \mathrm{~h}$ & NA & NA & $0.068(0.056-0.078)$ & 0.060 & 0.080 \\
\hline \multirow[t]{2}{*}{ Baseline test } & $24 \mathrm{~h}$ & NA & NA & $0.081(0.077-0.084)$ & 0.060 & 0.080 \\
\hline & $48 \mathrm{~h}$ & NA & NA & $0.073(0.064-0.074)$ & 0.060 & 0.080 \\
\hline \multirow[t]{2}{*}{ EDTA addition } & $24 \mathrm{~h}$ & 74.4 & 20 & $0.127(0.104-0.193)$ & 0.100 & $>0.100$ \\
\hline & $48 \mathrm{~h}$ & 74.4 & 20 & $0.079(0.071-0.083)$ & 0.060 & 0.080 \\
\hline \multirow[t]{2}{*}{$\mathrm{Na}_{2} \mathrm{~S}_{2} \mathrm{O}_{3}$ addition } & $24 \mathrm{~h}$ & 94.4 & 34 & $0.078(0.067-0.081)$ & 0.060 & 0.080 \\
\hline & $48 \mathrm{~h}$ & 94.4 & 34 & $0.041(0.024-0.058)$ & 0.060 & 0.080 \\
\hline \multirow[t]{2}{*}{ Post $\mathrm{C}_{18}$ column } & $24 \mathrm{~h}$ & - & - & $\mathrm{NST}^{\mathrm{e}}$ & - & - \\
\hline & $48 \mathrm{~h}$ & - & - & NST & - & - \\
\hline
\end{tabular}

${ }^{\mathrm{a}} \mathrm{EC}_{50}$ values and corresponding $95 \%$ confidence intervals in parentheses

${ }^{b}$ NOEC, no observed effect concentration, the highest observed concentration at which no significant effect $(p \leq 0.05)$ was detected

${ }^{c}$ LOEC, lowest observed effect concentration, the lowest concentration of the tested concentration at which a significant $(p \leq 0.05)$ effect was detected.

${ }^{\mathrm{d}} \mathrm{NA}=$ Not Applicable

${ }^{\mathrm{e}} \mathrm{NST}=$ No Significant Toxicity 


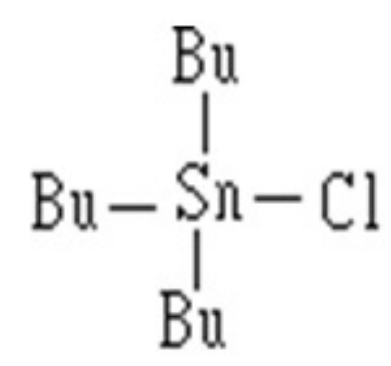

Tributyltin chloride<smiles>c1ccc2c(c1)cc1ccc3cccc4ccc2c1c34</smiles>

Benzo[a]pyrene

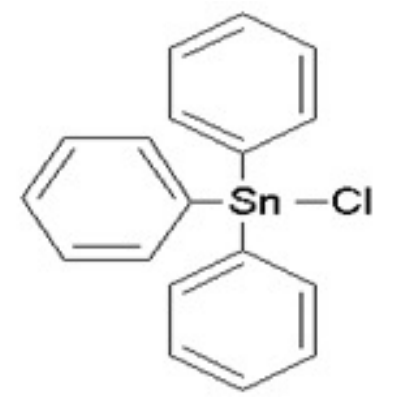

Triphenyltin chloride

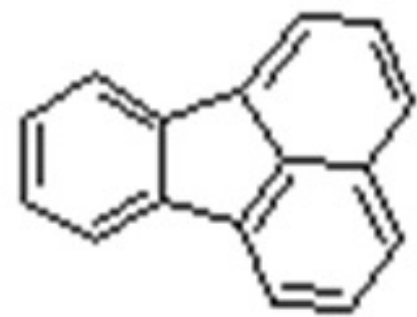

Fluoranthene<smiles>Clc1cc(Cl)c(-c2cc(Cl)c(Cl)cc2Cl)cc1Cl</smiles>

$2,2^{\prime}, 4,4^{\prime}, 5,5^{\prime}$-hexachl orobiphenyl (PCB 153)

1

2 Fig. 1. Chemical structures of test compounds.

3 


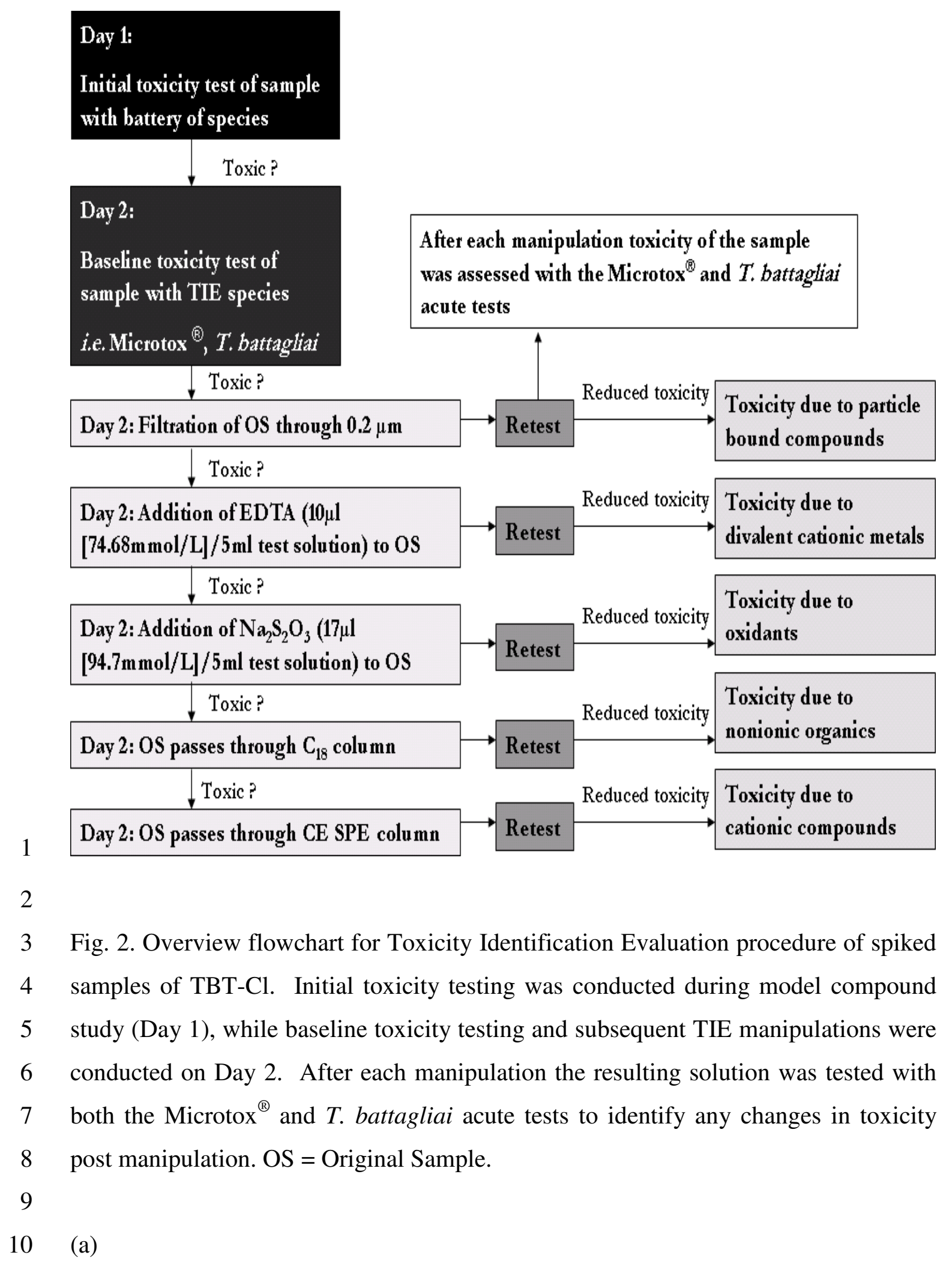




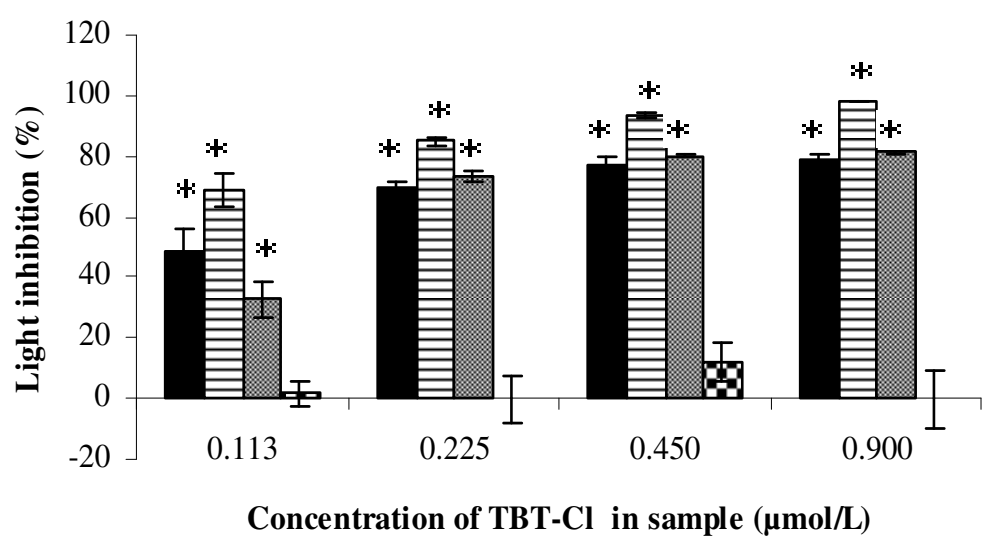

1

2

(b)

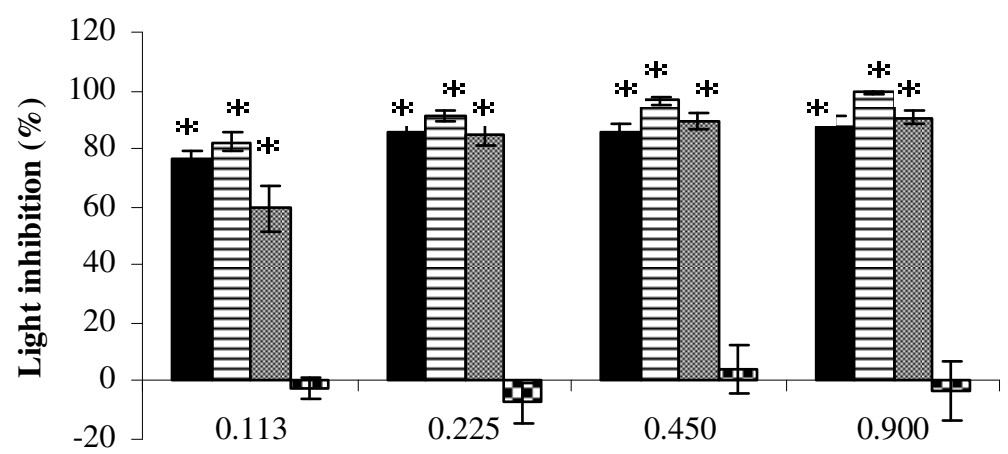

Concentration of TBT-Cl in sample $(\mu \mathrm{mol} / \mathrm{L})$

3

$4 \quad(c)$

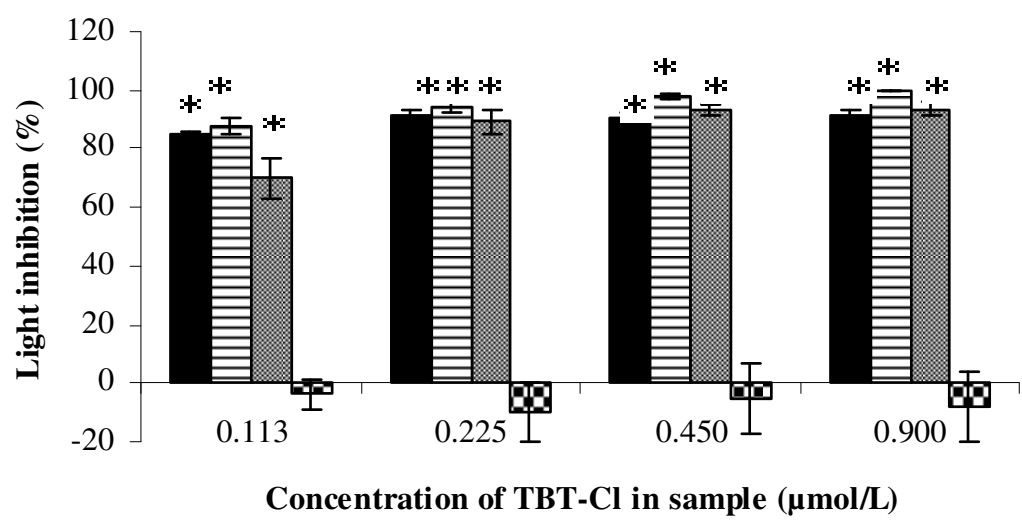

5 
1 Fig. 3. Percentage light inhibition of Vibrio fischeri exposed to spiked TBT-Cl sample

2 after Baseline testing ( $\square$ ), post EDTA addition (目), post $\mathrm{Na}_{2} \mathrm{~S}_{2} \mathrm{O}_{3}$ addition (10) and 3 post $\mathrm{C}_{18}$ (㭗) manipulation after (a) 5, (b) 15, and (c) 30 min exposure. Data are 4 expressed as a percentage of unexposed controls \pm SEM of three independent 5 experiments. $*$ denotes significance from the control $(p \leq 0.05)$.

6

7 
(a)
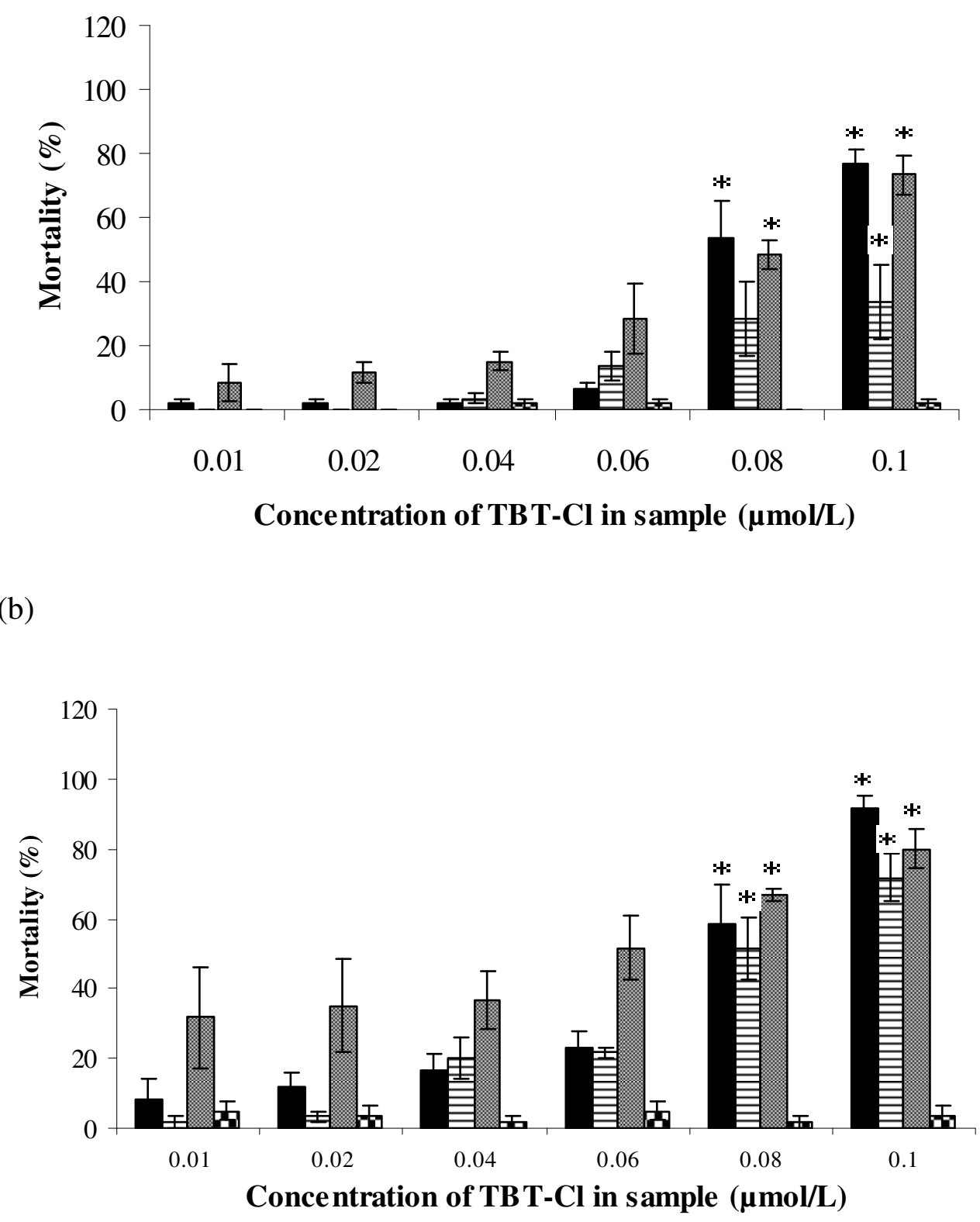

8 Fig. 4. Percentage mortality of T. battagliai exposure to spiked TBT-Cl sample after 9 Baseline testing ( $\square$ ), post EDTA addition (目), post $\mathrm{Na}_{2} \mathrm{~S}_{2} \mathrm{O}_{3}$ addition (䀳) and post $10 \mathrm{C}_{18}$ (粗) manipulation after (a) 24, and (b) $48 \mathrm{~h}$ exposure. Data are expressed as a 11 percentage of unexposed controls \pm SEM of three independent experiments. * 12 denotes significance from the control $(p \leq 0.05)$. 
Table 1. Ecotoxicity data from the literature on the compounds and species tested in this study

\begin{tabular}{|c|c|c|c|c|c|c|}
\hline $\begin{array}{l}\text { Trophic } \\
\text { level }\end{array}$ & Test Species & Chemical & $\begin{array}{l}\text { Exposure } \\
\text { Time } \\
\end{array}$ & Endpoint & Toxicity value & Reference \\
\hline Bacteria & Vibrio fisheri & $\begin{array}{l}\text { DMSO } \\
\text { TBT-Cl } \\
\text { TPT-Cl } \\
\text { TBT-Cl } \\
\text { TBT-Cl } \\
\text { TBT-Cl } \\
\text { TBT-Cl } \\
\text { FLA } \\
\text { FLA } \\
\text { TBT }\end{array}$ & $\begin{array}{l}\mathrm{NR} \\
15 \mathrm{~min} \\
15 \mathrm{~min} \\
5 \mathrm{~min} \\
15 \mathrm{~min} \\
5 \mathrm{~min} \\
15 \mathrm{~min} \\
15 \mathrm{~min} \\
18 \mathrm{~h} \\
30 \mathrm{~min}\end{array}$ & $\begin{array}{l}\mathrm{MAC} \\
\mathrm{EC}_{50} \\
\mathrm{EC}_{50} \\
\mathrm{EC}_{50} \\
\mathrm{EC}_{50} \\
\mathrm{EC}_{50} \\
\mathrm{EC}_{50} \\
\mathrm{EC}_{50} \\
\mathrm{EC}_{50} \\
\mathrm{EC}_{50}\end{array}$ & $\begin{array}{l}0.5 \% \\
0.029 \mu \mathrm{mol} / \mathrm{L} \\
0.052 \mu \mathrm{mol} / \mathrm{L} \\
0.022 \mathrm{mg} / \mathrm{L} \\
0.011 \mathrm{mg} / \mathrm{L} \\
7.0 \mu \mathrm{g} / \mathrm{L} \\
246.8 \mu \mathrm{gg} / \mathrm{L} \\
2.16 \mathrm{mg} / \mathrm{L} \\
80.99 \mathrm{mg} / \mathrm{L} \\
0.007 \pm 0.0012 \mathrm{mg} / \mathrm{L}\end{array}$ & $\begin{array}{l}\text { Kwan and Dutka, } 1990 \\
\text { Argese } \text { et al.,1998 } \\
\text { Argese } \text { et al.,1998 } \\
\text { Fernández-Alba } \text { et al., } 2002 \\
\text { Fernández-Alba } \text { et al., } 2002 \\
\text { Dooley and Denis, } 1987 \\
\text { Dooley and Denis, } 1987 \\
\text { El Alawi et al., } 2002 \\
\text { El Alawi et al., } 2002 \\
\text { Hernando } \text { et al., } 2003\end{array}$ \\
\hline Copepods & $\begin{array}{l}\text { Tisbe battagliai } \\
\text { Tisbe battagliai }\end{array}$ & $\begin{array}{l}\text { Acetone } \\
\text { FLA }\end{array}$ & $\begin{array}{l}26 \mathrm{~d} \\
4 \mathrm{~d}\end{array}$ & $\begin{array}{l}\mathrm{NR} \\
\mathrm{LC}_{50}\end{array}$ & $\begin{array}{l}25 \mu 1 / \mathrm{L} \\
0.063 \mathrm{mg} / \mathrm{L}\end{array}$ & $\begin{array}{l}\text { Bechmann, } 1999 \\
\text { Barata et al., } 2002\end{array}$ \\
\hline
\end{tabular}

DMSO = Dimethyl sulphoxide, NR = Not Reported, MAC $=$ Maximum Allowable Concentration, FLA = Fluoranthene, EC $_{50}=$ Effective Concentration of $50 \%$ of sample population, $\mathrm{LC}_{50}=$ Lethal concentration of $50 \%$ of sample population. 
Table 2. Reference chemical ecotoxicity data for battery test species and endpoints.

\begin{tabular}{llllll}
\hline Species & $\begin{array}{l}\text { Reference } \\
\text { chemical }\end{array}$ & $\begin{array}{l}\text { Exposure period and endpoint } \\
\end{array}$ & $\begin{array}{l}\text { EC/LC } \mathbf{5 0}^{\mathbf{a}} \\
(\mathbf{m g} / \mathbf{L})\end{array}$ & $\begin{array}{l}\text { Cited } \\
\text { value } \\
(\mathbf{m g} / \mathbf{L})\end{array}$ & $\begin{array}{l}\text { Reference } \\
\end{array}$ \\
\hline Vibrio fischeri & $\mathrm{C}_{6} \mathrm{H}_{6} \mathrm{O}$ & 5 min inhibition & $21.29(14.73-35.26)$ & $13-26$ & Azur Environmental $(1998)$ \\
Tetraselmis suecica & $\mathrm{K}_{2} \mathrm{Cr}_{2} \mathrm{O}_{7}$ & $72 \mathrm{~h}$ inhibition & $14.12(11.20-15.13)$ & - & \\
Tisbe battagliai & $\mathrm{K}_{2} \mathrm{Cr}_{2} \mathrm{O}_{7}$ & 48 h lethality & $7.42(5.73-10.01)$ & $1.6^{\mathrm{b}}$ & Hutchinson et al. (1994) \\
& & & & $5.9^{\mathrm{c}}$ & Hutchinson et al. (1994) \\
\hline
\end{tabular}

\footnotetext{
${ }^{\mathrm{a}} \mathrm{EC}_{50}$ values and corresponding $95 \%$ confidence intervals in parentheses

${ }^{\mathrm{b}} 96 \mathrm{~h} \mathrm{LC}_{50}$ value for nauplii
}

${ }^{\mathrm{c}} 96 \mathrm{~h} \mathrm{LC}_{50}$ value for adult females 
Table 3. Ecotoxicity data for all selected chemicals with Vibrio fischeri (Microtox ${ }^{\circledR}$ )

\begin{tabular}{|c|c|c|c|c|c|}
\hline Test chemical & Exposure time (min) & $\begin{array}{l}\text { Concentration range } \\
(\mu \mathrm{mol} / \mathrm{L})\end{array}$ & $\mathrm{EC}_{50}{ }^{\mathrm{a}}(\mu \mathrm{mol} / \mathrm{L})$ & $\operatorname{NOEC}(\mu \mathrm{mol} / \mathrm{L})^{\mathrm{b}}$ & $\mathrm{LOEC}(\mu \mathrm{mol} / \mathrm{L})^{\mathrm{c}}$ \\
\hline \multirow[t]{2}{*}{ TBT-Cl } & 5 & $0.004-0.900$ & $0.129(0.124-0.224)$ & 0.056 & 0.113 \\
\hline & 30 & $0.004-0.900$ & $0.059(0.055-0.080)$ & 0.028 & 0.056 \\
\hline \multirow[t]{2}{*}{ TPT-Cl } & 5 & $0.004-0.900$ & $0.584(0.400-0.802)$ & 0.225 & 0.450 \\
\hline & 30 & $0.004-0.900$ & $0.184(0.103-0.247)$ & 0.113 & 0.225 \\
\hline \multirow[t]{3}{*}{$\mathrm{B}[\mathrm{a}] \mathrm{P}$} & 5 & $0.588-150.740$ & $70.026(55.821-85.755)$ & 9.421 & 18.843 \\
\hline & 15 & $0.588-150.740$ & $154.071(121.721-202.150)^{\mathrm{d}}$ & 18.843 & 37.685 \\
\hline & 30 & $0.588-150.740$ & $230.777(143.996-832.610)^{\mathrm{d}}$ & 75.370 & 150.740 \\
\hline
\end{tabular}

${ }^{\mathrm{a}} \mathrm{EC}_{50}$ values and corresponding $95 \%$ confidence intervals in parentheses

${ }^{b}$ NOEC, no observed effect concentration, the highest observed concentration at which no significant effect $(p \leq 0.05)$ was detected

${ }^{c}$ LOEC, lowest observed effect concentration, the lowest concentration of the tested concentration at which a significant $(p \leq 0.05)$ effect was detected.

${ }^{\mathrm{d}} \mathrm{EC}_{50}$ values and corresponding $95 \%$ confidence intervals calculated by extrapolation of the data by REGTOX-EV6.xls 
Table 4. Ecotoxicity data for all selected chemicals with Tisbe battagliai.

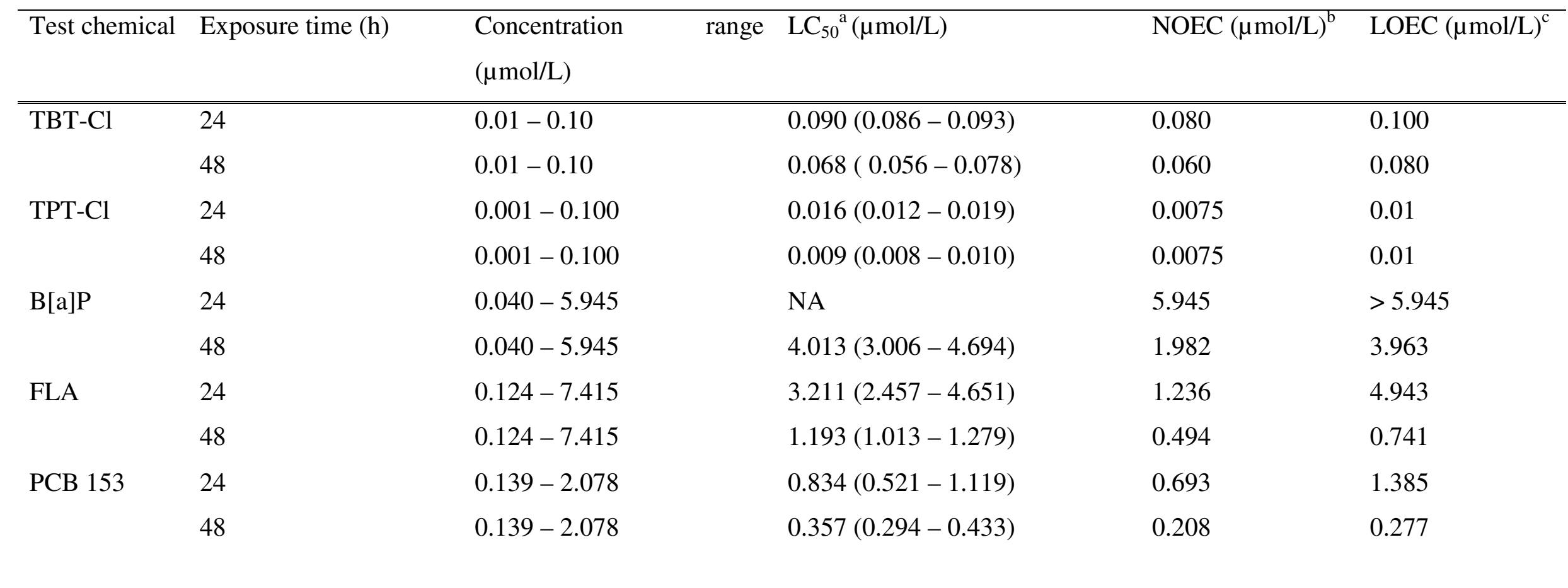

\footnotetext{
${ }^{\mathrm{a}} \mathrm{LC}_{50}$ values and corresponding $95 \%$ confidence intervals in parentheses

${ }^{b}$ NOEC, no observed effect concentration, the highest observed concentration at which no significant effect $(p \leq 0.05)$ was detected

${ }^{c}$ LOEC, lowest observed effect concentration, the lowest concentration of the tested concentration at which a significant $(p \leq 0.05)$ effect was detected.

NA $=$ Not Applicable
} 
Table 5. Ecotoxicity data for all TIE manipulation on spiked sample of TBT-Cl (top concentration of $0.9 \mu$ mol/L) and the Microtox ${ }^{\circledR}$ acute toxicity test

\begin{tabular}{|c|c|c|c|c|c|c|c|}
\hline Manipulation & $\begin{array}{l}\text { Exposure } \\
\text { time (min) }\end{array}$ & $\begin{array}{l}\text { Concentration of } \\
\text { reagent stocks } \\
(\mathrm{mmol} / \mathrm{L})\end{array}$ & $\begin{array}{l}\text { Volume of reagent } \\
\text { stocks }(\mu \mathrm{l})\end{array}$ & Test type & $\mathrm{EC}_{50}(\mu \mathrm{mol} / \mathrm{L})^{\mathrm{a}}$ & $\begin{array}{l}\text { NOEC } \\
(\mu \mathrm{mol} / \mathrm{L})^{\mathrm{b}}\end{array}$ & $\begin{array}{l}\text { LOEC } \\
(\mu \mathrm{mol} / \mathrm{L})^{\mathrm{c}}\end{array}$ \\
\hline \multirow[t]{3}{*}{ Initial toxicity test } & 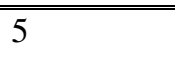 & $\mathrm{NA}^{\mathrm{d}}$ & NA & $90 \%$ test & $0.129(0.124-0.224)$ & 0.056 & 0.113 \\
\hline & 15 & NA & NA & $90 \%$ test & $0.083(0.078-0.132)$ & 0.028 & 0.056 \\
\hline & 30 & NA & NA & $90 \%$ test & $0.059(0.055-0.080)$ & 0.028 & 0.056 \\
\hline \multirow[t]{3}{*}{ Baseline test } & 5 & NA & NA & Basic test & $0.152(0.131-0.191)$ & $<0.1125$ & 0.1125 \\
\hline & 15 & NA & NA & Basic test & $0.079(0.044-0.104)$ & $<0.1125$ & 0.1125 \\
\hline & 30 & NA & NA & Basic test & $0.057(0.022-0.083)$ & $<0.1125$ & 0.1125 \\
\hline \multirow[t]{3}{*}{ EDTA addition } & 5 & 74.4 & 10 & Basic test & $0.070(0.052-0.087)$ & $<0.1125$ & 0.1125 \\
\hline & 15 & 74.4 & 10 & Basic test & $0.098(0.037-0.100)$ & $<0.1125$ & 0.1125 \\
\hline & 30 & 74.4 & 10 & Basic test & $0.027(0.009-0.050)$ & $<0.1125$ & 0.1125 \\
\hline \multirow[t]{3}{*}{$\mathrm{Na}_{2} \mathrm{~S}_{2} \mathrm{O}_{3}$ addition } & 5 & 94.9 & 17 & Basic test & $0.153(0.130-0.192)$ & $<0.1125$ & 0.1125 \\
\hline & 15 & 94.9 & 17 & Basic test & $0.079(0.042-0.104)$ & $<0.1125$ & 0.1125 \\
\hline & 30 & 94.9 & 17 & Basic test & $0.057(0.018-0.084)$ & $<0.1125$ & 0.1125 \\
\hline \multirow[t]{3}{*}{ Post $\mathrm{C}_{18}$ column } & 5 & - & - & Basic test & $\mathrm{NST}^{\mathrm{e}}$ & - & - \\
\hline & 15 & - & - & Basic test & NST & - & - \\
\hline & 30 & - & - & Basic test & NST & - & - \\
\hline
\end{tabular}

\footnotetext{
${ }^{\mathrm{a}} \mathrm{EC}_{50}$ values and corresponding $95 \%$ confidence intervals in parentheses

${ }^{\mathrm{b}} \mathrm{NOEC}$, no observed effect concentration, the highest observed concentration at which no significant effect $(p \leq 0.05)$ was detected

${ }^{c}$ LOEC, lowest observed effect concentration, the lowest concentration of the tested concentration at which a significant $(p \leq 0.05)$ effect was detected.

${ }^{\mathrm{d}} \mathrm{NA}$, Not Applicable

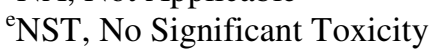


Table 6 Ecotoxicity data for all TIE manipulation on spiked sample of TBT-Cl (top concentration of $0.1 \mu$ mol/L) and the T. battagliai acute toxicity test

\begin{tabular}{|c|c|c|c|c|c|c|}
\hline Manipulation & $\begin{array}{l}\text { Exposure } \\
\text { time (min) }\end{array}$ & $\begin{array}{l}\text { Concentration of } \\
\text { reagent stocks } \\
(\mathrm{mmol} / \mathrm{L})\end{array}$ & $\begin{array}{l}\text { Volume of } \\
\text { reagent stocks } \\
(\mu 1)\end{array}$ & $\mathrm{EC}_{50}(\mu \mathrm{mol} / \mathrm{L})^{\mathrm{a}}$ & $\begin{array}{l}\text { NOEC } \\
(\mu \mathrm{mol} / \mathrm{L})^{b}\end{array}$ & $\begin{array}{l}\text { LOEC } \\
(\mu \mathrm{mol} / \mathrm{L})^{\mathrm{c}}\end{array}$ \\
\hline \multirow[t]{2}{*}{ Initial toxicity test } & $24 \mathrm{~h}$ & $\mathrm{NA}^{\mathrm{d}}$ & NA & $0.090(0.086-0.093)$ & 0.080 & 0.100 \\
\hline & $48 \mathrm{~h}$ & NA & NA & $0.068(0.056-0.078)$ & 0.060 & 0.080 \\
\hline \multirow[t]{2}{*}{ Baseline test } & $24 \mathrm{~h}$ & NA & NA & $0.081(0.077-0.084)$ & 0.060 & 0.080 \\
\hline & $48 \mathrm{~h}$ & NA & NA & $0.073(0.064-0.074)$ & 0.060 & 0.080 \\
\hline \multirow[t]{2}{*}{ EDTA addition } & $24 \mathrm{~h}$ & 74.4 & 20 & $0.127(0.104-0.193)$ & 0.100 & $>0.100$ \\
\hline & $48 \mathrm{~h}$ & 74.4 & 20 & $0.079(0.071-0.083)$ & 0.060 & 0.080 \\
\hline \multirow[t]{2}{*}{$\mathrm{Na}_{2} \mathrm{~S}_{2} \mathrm{O}_{3}$ addition } & $24 \mathrm{~h}$ & 94.4 & 34 & $0.078(0.067-0.081)$ & 0.060 & 0.080 \\
\hline & $48 \mathrm{~h}$ & 94.4 & 34 & $0.041(0.024-0.058)$ & 0.060 & 0.080 \\
\hline \multirow[t]{2}{*}{ Post $C_{18}$ column } & $24 \mathrm{~h}$ & - & - & $\mathrm{NST}^{\mathrm{e}}$ & - & - \\
\hline & $48 \mathrm{~h}$ & - & - & NST & - & - \\
\hline
\end{tabular}

${ }^{\mathrm{a}} \mathrm{EC}_{50}$ values and corresponding $95 \%$ confidence intervals in parentheses

${ }^{\mathrm{b}}$ NOEC, no observed effect concentration, the highest observed concentration at which no significant effect $(p \leq 0.05)$ was detected

${ }^{c}$ LOEC, lowest observed effect concentration, the lowest concentration of the tested concentration at which a significant $(p \leq 0.05)$ effect was detected.

${ }^{\mathrm{d}} \mathrm{NA}=$ Not Applicable

${ }^{\mathrm{e}} \mathrm{NST}=$ No Significant Toxicity 